\title{
A collaborative approach for urban underground space development toward sustainable development goals: Critical dimensions and future directions
}

\author{
Fang-Le PENG $^{a^{*}}$, Yong-Kang QIAO $^{a, b}$, Soheil SABRI ${ }^{\mathrm{b}}$, Behnam ATAZADEH ${ }^{\mathrm{b}}$, Abbas RAJABIFARD ${ }^{\mathrm{b}}$ \\ ${ }^{a}$ Research Center for Underground Space \& Department of Geotechnical Engineering, Tongji University, Shanghai 200092, China \\ ${ }^{b}$ Department of Infrastructure Engineering, University of Melbourne, Melbourne, VIC 3010, Australia \\ *Corresponding author. E-mail: pengfangle@tongji.edu.cn
}

(C) Higher Education Press 2021

\begin{abstract}
The utilization of urban underground space (UUS) offers an effective solution to urban problems but may also negatively affect urban development. Therefore, UUS development needs better concerted guidelines to coordinate various urban systems and the multiple components of the underground world. Sustainable Development Goals (SDGs), which should be viewed as important yardsticks for UUS development, do not explicitly mention urban underground space, although many of them are affected by both the positive and negative consequences of its development. To fill this gap, this review lays the foundations of relevant UUS concepts and uses exemplary cases to reveal that 11 out of 17 SDGs can be linked with UUS uses. These linkages also manifest that land administration, integrated planning, architectural design, and construction technology are critical dimensions for increasing the contributions of UUS to the realization of SDGs. To achieve multi-disciplinary synergies among these four critical dimensions, a collaborative approach framework based on spatial data infrastructure is required. Thus, this work provides academics and practitioners with a holistic view of sustainable UUS development.
\end{abstract}

KEYWORDS urban underground space, Sustainable Development Goals, spatial data infrastructure, underground land administration, integrated planning

\section{Introduction}

According to Engineering Fronts, the development and utilization of urban underground space (UUS) is among the top 10 development fronts of civil, hydraulic, and architectural engineering [1]. The numbers of core patents published in the above report show that UUS use and ecofriendly building materials are currently the main development trends of civil, hydraulic, and architectural engineering, being driven by global urbanization and sustainable development. As the ever-increasing urbanization rate imposes more land use pressure on densely populated cities in both developing and developed countries, the utilization of UUS as an important land resource is attracting much attention. In China, as an

Article history: Received Jun 4, 2020; Accepted Aug 23, 2020 exemplary developing country, the total length of operational rail transit lines (most of which are underground) and utility tunnels under construction surpassed 5000 and $7800 \mathrm{~km}$, respectively, in 2018 [2]. In Tokyo, Japan, more than $99.9 \%$ of the existing buildings are equipped with basements within the equivalent of four stories, and the basement of Tokyo Skytree is $\sim 35 \mathrm{~m}$ deep, featuring heating equipment and water retention facilities [3]. Even the sparsely populated city of Melbourne refers to UUS to improve transportation capacity, as exemplified by the current West Gate Tunnel and Metro Tunnel projects.

In addition, UUS use is viewed as a sustainable means of urbanization [4-6]. However, sustainability is a broad topic in that there is no yardstick to measure the relevant contributions yielded by UUS use. The emergence of Sustainable Development Goals (SDGs), adopted by 193 member states of the United Nations (UN) in 2015, 
provides a plausible solution to fill this gap. Building on the unrealized UN Millennium Development Goals (MDGs) [7], SDGs not just extend MDGs on people's welfare (e.g., poverty, health, education, and gender equality) but also stress the significance of safeguarding Earth's life support systems (e.g., water, energy, climate, biodiversity, and ecosystems) [8]. The 17 ambitious SDGs and the corresponding 169 specific targets are anticipated to be implemented by 2030 [9]. However, according to a recent UN report, the global transformation required for SDGs' realization is "not yet advancing at the speed or scale required" [10], partly because SDGs cover broad dimensions that increase the complexity of striking a balance between meeting the essential needs of humans and the expected objectives to safeguard the Earth [11]. To address this issue, extensive research efforts have been made to reveal the linkages, such as synergies and tradeoffs, between SDGs and various domains such as water [12], soil [13], farmers [14], energy [15], fire [16], ecosystem [17], textiles [18], non-residential buildings [19], and new urban policies [20]. Evidently, the number of revealed linkages is positively correlated with the possibility that they contribute to SDGs via different aspects. In this respect, the UN Human Settlements Programme (the coordinating agency in the implementation of SDGs, particularly the Goal 11 of "Making cities and human settlements inclusive, safe, resilient, and sustainable", hereinafter referred to as "UN-Habitat") and the Associated Research Centers for the Urban Underground Space (the leading international non-governmental association in promoting UUS use and development, hereinafter referred to as "ACUUS") recognize the significance of collaboration in raising awareness of UUS contributions to urban sustainability and resilience, as reflected in the renewed Memorandum of Understanding (signed on October, 2019). However, the collaborative efforts would be largely useless if one cannot explicitly show how UUS contributes to SDGs.

The establishment of the above contributions is one of the major motives of this study. Section 2 lays the conceptual foundation for the whole paper, as different studies are likely to confuse many of the concepts related to UUS, such as UUS and urban underground infrastructure (UUI), underground resources and underground assets, and UUS services and geosystem services. These concepts are closely related to the linkages between UUS and SDGs and the relevant SDG targets, as is elaborated in Section 3 using exemplary cases and state-of-the-art research findings. The linkages between UUS and SDGs can be categorized into positive contributions, potential damages, and collaborative approaches. Collaborative approaches mean that SDGs require UUS development to establish "soft" measures such as institutions, administration, planning, and design for maximizing positive effects and minimizing negative ones. In Section 4, four critical dimensions of the collaborative approach for UUS development, namely modern land administration, integrated planning, architectural design, and construction technology, are reviewed to elicit the requirements for each dimension. A spatial data infrastructure (SDI)-based framework is then proposed in Section 5 to meet the requirements of the four critical dimensions and this aid SDGs' delivery. Finally, Section 6 summarizes the findings and future outlooks of UUS development.

\section{Conceptual foundations for UUS research}

\subsection{UUS and UUI}

In general, underground space can be literally defined as a geospace situated beneath the ground level $[21,22]$, which is also referred to as subsurface space, subterranean space, or simply the underground and the subsurface in related studies. From a broader perspective, underground space includes everything, either biotic or abiotic, that exists between the ground surface and Earth's core. The significance of underground space use in urban areas has been frequently highlighted as a means of addressing the problems caused by rapid urbanization. Therefore, the term "UUS" has been widely accepted in both industry and academia, with typical UUS characteristics including isolation from the external environment, temperature stability, protection by soils or rocks, and high development cost [23]

However, UUS is often confused with the manmade space beneath cities, such as utility pipelines, tunnels, building basements, and garages. These facilities are some of the major concerns of decision-makers and planning practitioners, who generally refer to UUS use to accommodate various urban functions such as storage, industry, transport, utilities and communications, public service, and civil defense. This strategy is considered to effectively extend the limited urban space for meeting the demands of the ever-increasing population. Specifically, such manmade space should be named UUI, which can be defined as the artificially excavated physical space beneath the ground level of a city surrounded by rock or soil mass [22].

\subsection{Underground resources and underground assets}

The concept of underground resources emerged from the DEEP CITY project, in which physical space, geothermal energy, groundwater, and geomaterials are identified as underground resource potentials [4,24-27]. These research efforts show that underground resources are valuable subsets of UUS, while UUI, which one can consider to be equivalent to physical space, is one of the sub-categories of underground resources.

Bobylev [23] and Sterling et al. [28] further classified underground resources as non-renewable resources (which include physical space, space continuum, geo-environ- 
mental properties, underground flora/fauna, and excavated materials) and cultural heritage and renewable resources (which include groundwater and geothermal energy). Similarly, Qiao et al. [29] also proposed underground assets that allegedly contribute to urban sustainability. Given that the traditional definition of resources hardly covers living organisms (flora, fauna, and microorganisms), this study suggests that the term "underground assets" is a better choice and should at least cover the aspects listed in Table 1. It should be noted that the underground assets in the present review refer to physical (or tangible) assets that have a material existence rather than to the virtual (or intangible) assets such as the rights, restrictions, and responsibilities attached to land parcels.

\subsection{UUS services and geosystem services}

UUS services refer to urban services derived from UUS use. Every underground asset can contribute to cities and societies in a certain way. The concept of UUS services was put forward by Qiao et al. [30,31], who assessed the benefits of UUS use in monetary terms. However, only UUS services derived from UUI were employed in these works.

Another similar concept is geosystem services, which are provided by the geosphere and represented by abiotic

Table 1 Underground assets (according to Ref. [29])

\begin{tabular}{lc}
\hline assets & descriptions \\
\hline physical space (UUI) & $\begin{array}{c}\text { UUI refers to artificially excavated } \\
\text { physical space surrounded by rock or } \\
\text { soil mass beneath the ground level of a } \\
\text { city. }\end{array}$ \\
geothermal energy & $\begin{array}{c}\text { Geothermal energy is the thermal } \\
\text { energy generated and stored in a } \\
\text { subterranean way. }\end{array}$
\end{tabular}

groundwater

Groundwater generally occurs in three sorts of aquifers, i.e., perched, unconfined, and confined ones.

geomaterials

Geomaterials include sand, clay, rocks, and minerals buried underground.

historical heritage

space continuum

underground organisms products and services. Such services are distinctive from ecosystem services, which are provided by biomes and marine ecosystems. The concept was originally created to address the subsurface and its contributions to human welfare [32,33] and geodiversity conservation [34].

Despite the large overlap, there is no inclusion relation between UUS services and geosystem services. The latter services can be provided by surface or aboveground abiotic environments and underground assets outside urban areas but exclude the services of underground organisms. Therefore, to cover UUS contributions, the present review suggests the concept of UUS services, which can be categorized into direct and external services. External services are generated by the indirect impacts of UUS use, as summarized in Table 2.

Table 2 UUS services (according to Refs. [23,30,32])

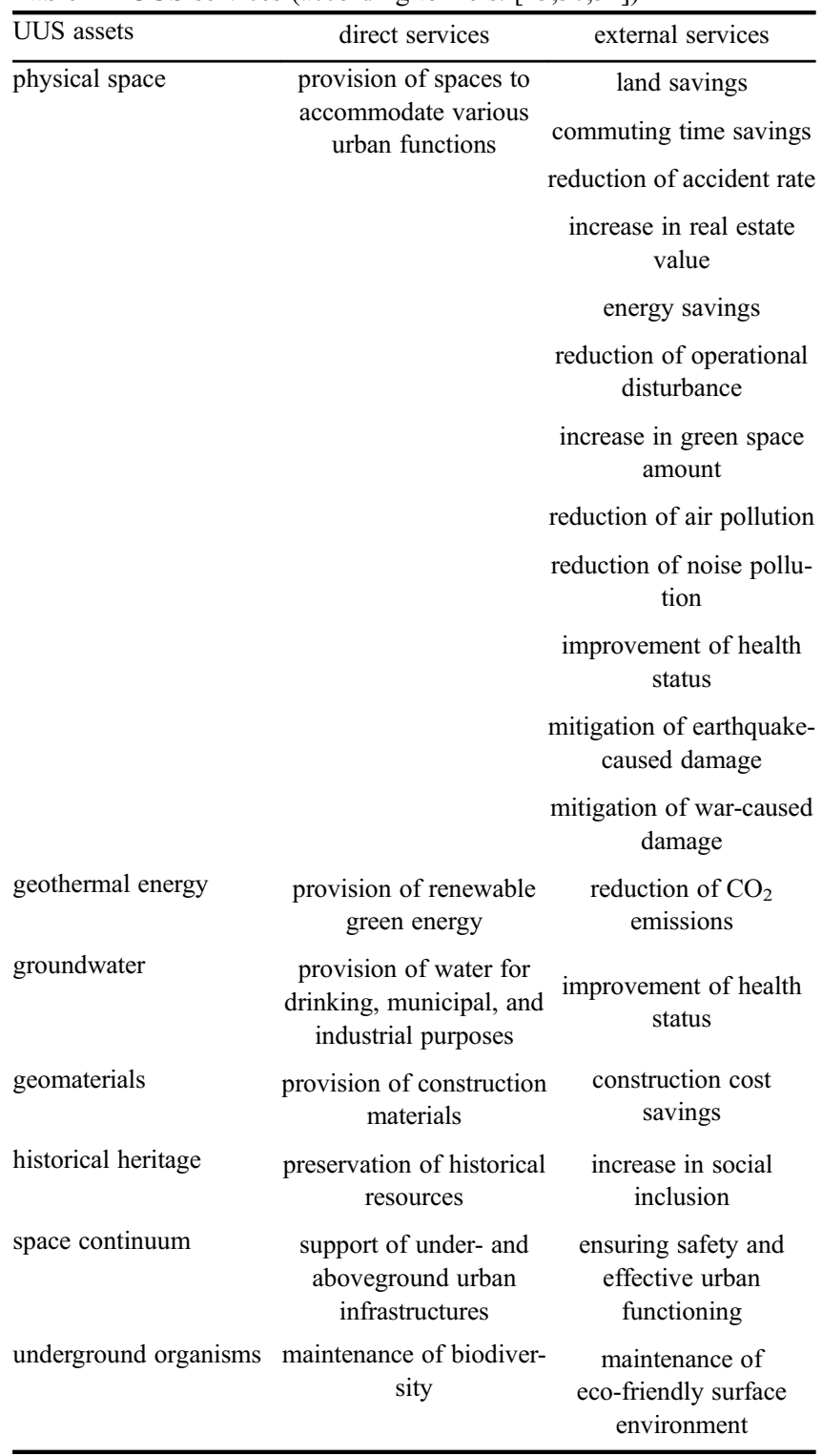




\section{Role of UUS in achieving SDGs}

\subsection{Linkages between SDGs and UUS}

As SDGs are a rather new concept introduced only in 2015, they are not mentioned in most works on UUS. However, several of these works deal with the sustainability issues of UUS use and can be broadly categorized into those focusing on the contributions of UUS use to urban sustainability [4-6] and those concerned with the sustainable use of UUS itself $[28,35,36]$. However, both types are interactive, because more often than not, the influences imposed on urban development are considered as an indicator of the sustainable use of UUS. As for the linkages between UUS and urban sustainability, various methods are referred to in the aforementioned references. Zargarian et al. [35] modified the framework of the Sustainable Project Appraisal Routine (SPeAR) based on the three pillars of sustainable development, i.e., environment, society, and economy. Hunt et al. [36] adopted the toolkit of "Urban Future" to explore the possible links between UUS use and urban sustainability within four plausible future scenarios, i.e., from the viewpoints of the new sustainability paradigm, fortress world, market forces, and the policy reform, while other researchers broke down the sustainability contributions of UUS use simply using contextual narratives.

Obviously, there are no unified criteria available for the sustainability analysis of UUS use, largely because of the unquantifiable definition of sustainable development. In this regard, SDGs, along with detailed targets and measurable indicators, can be useful tools. However, SDGs do not explicitly mention UUS, although many of them are affected by the beneficial and adverse consequences of the development of UUS and other relevant underground assets. It should be noted that most of UUS services, both direct and external (Table 2), can be linked with SDGs. In other words, although UUS contributes to SDGs, the policymakers are not well aware of these linkages. To fill this gap, this synthesis maps the linkages between SDGs and UUS (Table 3), which can be understood from contributing, detrimental, and collaborative perspectives. This means that UUS can make positive contributions or inflict detrimental damage to SDGs or the need to meet the instrumental requirements set up by SDGs. These three perspectives are detailed in the following three subsections.

\subsection{Exemplary cases of UUS contributing to SDGs}

1) SDG 3: good health and well-being. Underground transport facilities are the principal contributors to SDG 3. Rail transport, which is generally placed underground in metropolises, is much safer for both passengers and goods than other means of transport [37]. In addition, road tunnels for motor vehicles can increase driver cautiousness and decrease the impacts of bad weather, thereby reducing the accident rate [38] (Target 3.6). It is estimated that the overall accident rate fell by $\sim 50 \%$ after the completion of M30 project $(56 \mathrm{~km}$ of the total length of $99 \mathrm{~km}$ is in tunnels) in Madrid, Spain [39]. Meanwhile, rail and road tunnels can also help to reduce air pollution. The operation of the Taipei metro reduced air pollution from one tailpipe pollutant, carbon monoxide, by 5\%-15\% [40], which is one of the key drivers for the development of underground transport in Ljubljana, Slovenia [41]. In general terms, the smooth traffic flow in road tunnels can reduce vehicle emissions by decreasing the stop and go frequency [39]. Moreover, in road tunnels, there is a much higher likelihood of implementing air treatment techniques, which can significantly reduce the amount of emitted pollutants such as particulate matter (PM), $\mathrm{NO}_{x}, \mathrm{CO}$, volatile organic compound (VOC), and $\mathrm{SO}_{2}$ [42]. In addition, drainage and sewage tunnels connected with treatment plants help to improve the quality of both surface water and groundwater, especially in densely populated areas, as observed for the Suzhou River deep drainage tunnel in Shanghai [43] and the drainage and sewage tunnel networks in the Victoria Harbor area [44]. The reduction of air and water pollution improves people's health status and thus lowers the risks of illness and death (Target 3.9).

2) SDG 6: clean water and sanitation. Groundwater is an essential source of drinking water, accounting for $97 \%$ of the global fresh water supply [45]. Groundwater for drinking is generally distributed in perched, unconfined, and confined aquifers, which can be easily affected by urban activities. Therefore, the scientific management of these aquifers (Targets 6.5 and 6.6) and the safeguarding of groundwater from pollution are the prerequisites for the availability of safe and affordable drinking water, which in urban areas is principally accessed and stored using water supply pipelines and water storage ponds buried underground (Target 6.1). As stated above, drainage and sewage tunnels connected with treatment plants are attracting increased attention as means of improving water quality (Target 6.2).

3) SDG 7: affordable and clean energy. The green and renewable geothermal energy can be used for electricity generation, direct heat supply, and energy-efficient space heating and cooling. It is anticipated that by 2050 , geothermal electricity generation could reach $1400 \mathrm{TWh}$ per year, accounting for $3.5 \%$ of the global electricity production, with geothermal heat potentially contributing $5.8 \mathrm{EJ}$ (1600 TWh thermal energy) annually, that is, 3.9\% of the projected final energy for heat [46] (Target 7.2). UUI such as aquifer thermal energy storage facilities and borehole thermal energy systems provide users with access to the increasingly important modern energy (Target 7.1).

4) SDG 8: decent work and economic growth. The UUS is a sophisticated system, and the related uncertainties and 
Table 3 Linkages between SDGs and UUS

\begin{tabular}{|c|c|c|c|}
\hline SDGs & Targets & relevant excerpts & UUS contributors \\
\hline SDG 3: good health and well-being & 3.6 & $\begin{array}{l}\text { deaths and injuries from road traffic } \\
\text { accidents }\end{array}$ & UUI, groundwater \\
\hline \multirow[t]{3}{*}{ SDG 6: clean water and sanitation } & 6.1 & $\begin{array}{c}\text { access to safe and affordable drinking } \\
\text { water }\end{array}$ & UUI, groundwater \\
\hline & 6.5 & water resource management at all levels & \\
\hline & 6.6 & $\begin{array}{c}\text { water-related ecosystems, including } \\
\text { aquifers }\end{array}$ & \\
\hline SDG 7: affordable and clean energy & 7.1 & $\begin{array}{l}\text { access to affordable, reliable, and mod- } \\
\text { ern energy services }\end{array}$ & geothermal energy \\
\hline & 8.2 & technological upgrading and innovation & \\
\hline & 8.3 & $\begin{array}{l}\text { productive activities and growth of } \\
\text { micro-, small-, and medium-sized } \\
\text { enterprises }\end{array}$ & \\
\hline & 8.4 & resource efficiency in production & \\
\hline \multirow[t]{3}{*}{$\begin{array}{l}\text { SDG 9: industry, innovation, and infra- } \\
\text { structure }\end{array}$} & 9.1 & $\begin{array}{l}\text { development of quality, reliable, sus- } \\
\text { tainable, and resilient infrastructure }\end{array}$ & UUI \\
\hline & 9.2 & $\begin{array}{l}\text { industry's share of employment and } \\
\text { gross domestic product }\end{array}$ & all \\
\hline & 9.4 & $\begin{array}{l}\text { upgrading of infrastructure and retro- } \\
\text { fitting of industries with environmen- } \\
\text { tally sound technologies and industrial } \\
\text { processes }\end{array}$ & \\
\hline & 11.3 & $\begin{array}{l}\text { enhancing inclusive and sustainable } \\
\text { urbanization and capacity for participa- } \\
\text { tory, integrated and sustainable urbani- } \\
\text { zation and sustainable human settlement } \\
\text { planning }\end{array}$ & all, CA \\
\hline & 11.4 & $\begin{array}{l}\text { protection and safeguarding of the } \\
\text { world's cultural and natural heritage }\end{array}$ & historical heritage \\
\hline & 11.5 & $\begin{array}{l}\text { decrease of direct economic losses } \\
\text { caused by disasters, including water- } \\
\text { related disasters }\end{array}$ & UUI \\
\hline & 11.6 & $\begin{array}{l}\text { reduction of the adverse per capita } \\
\text { environmental impact of cities, includ- } \\
\text { ing air quality, municipal and other } \\
\text { waste management }\end{array}$ & UUI, geothermal energy, geomaterials \\
\hline & 11.7 & $\begin{array}{l}\text { safe, inclusive, and accessible green and } \\
\text { public spaces }\end{array}$ & UUI \\
\hline & 11.6 & $\begin{array}{l}\text { policies and plans toward inclusion, } \\
\text { resource efficiency, resilience to disas- } \\
\text { ters }\end{array}$ & all, CA \\
\hline
\end{tabular}


(Continued)

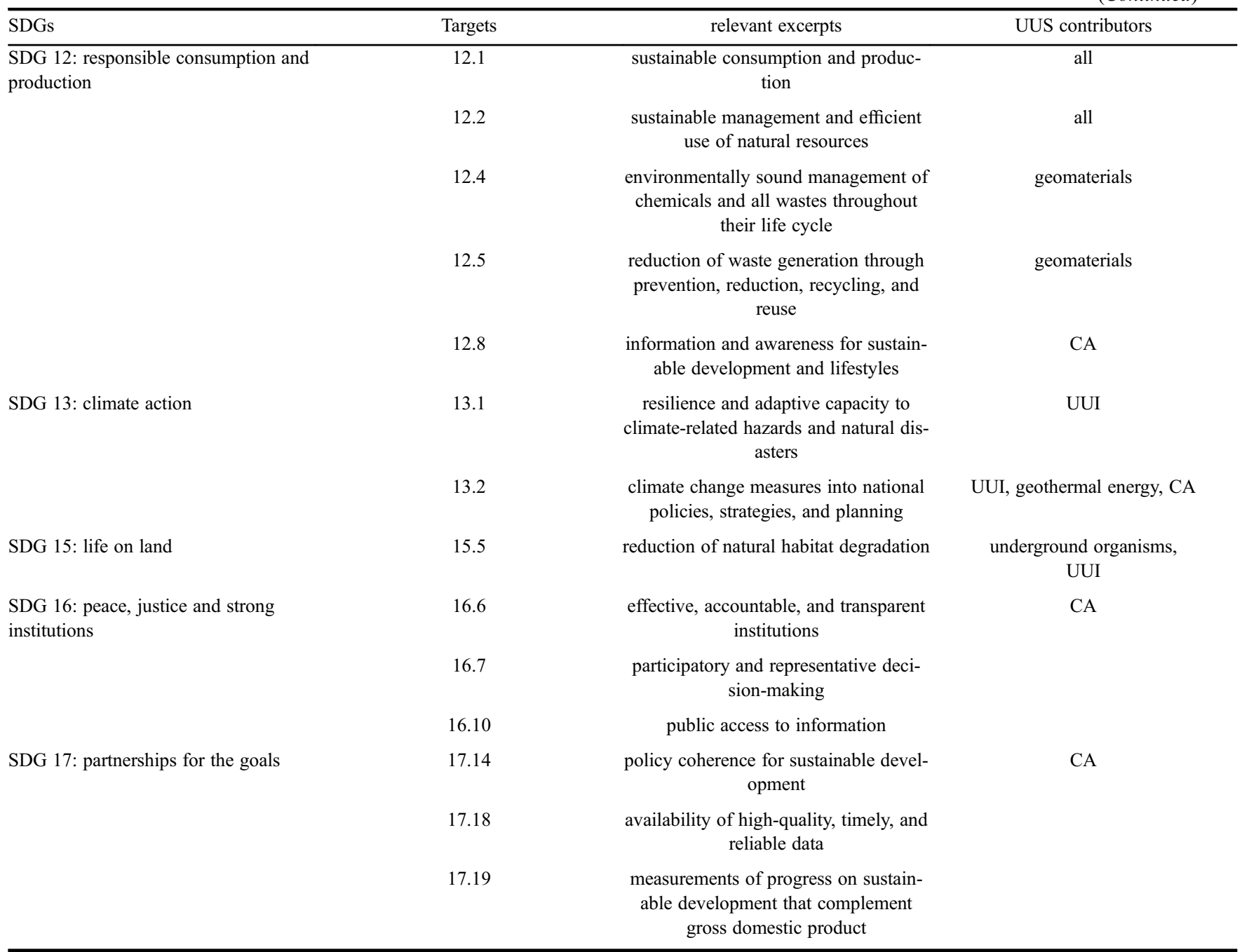

*Note: "all" means that all UUS assets listed in Table 1 contribute to SDGs. "CA" refers to "collaborative approach" and means that UUS development needs such an approach to achieve the relevant targets.

complexity make UUS engineering a technology-intensive urban activity. More sound and robust exploitation crafts and the corresponding equipment are required to minimize external impacts on UUS systems and surface urban activities (Target 8.2) and maximize the UUS resource efficiency (Target 8.4). Meanwhile, UUS development is also a driving force for the local economy. For instance, the completed urban rail transit introduced a gross investment of over 2633 billion Yuan ( 405 billion 2016 US\$) to China [47] (Target 8.1) and boosted the growth of enterprises involved in the industrial chain (Target 8.3). It is planned that by 2020 , the total length of urban rail transit lines in China will reach $10000 \mathrm{~km}$, while by 2025 , the rail transport industry should be retrofitted in terms of technology and manufacture with the support of the national strategy "Made in China 2025" [48]. Another contribution of UUS to work and economy comes from the underground transport facilities. The decreased commuting time and alleviated business trip delays due to increased traffic efficiency and better traffic organization are beneficial for productive activities [49] (Target 8.3).

5) SDG 9: industry, innovation, and infrastructure. In addition to the industrial (Target 9.2) and technological (Target 9.5) perspectives of UUS development addressed in SDG 8, UUS can further enrich the capabilities of the industrial technology (Target 9.5), in particular those of the precision manufacturing industry, as exemplified by the Yamazaki Mazak Optonics Minokamo Factory [3]. Moreover, UUI is an important component of urban infrastructure. The surrounding soil or rock medium endows UUI with the potential for quality, reliable, sustainable, and resilient infrastructure (Target 9.1). However, it also restrains UUI from further expansion to meet the growing demands. These factors should be fully incorporated in the decision-making process. As no two cities are the same, the standpoints of UUI development vary but generally cover Target 9.1. For instance, Shanghai, China, lays out security, resilience, and ecology as the three priorities for 
the development of deep underground infrastructures. Under these strategies, four deep underground projects, including the Shanghai North Cross Channel (expressway road tunnel), the Shanghai Deep Drainage Tunnel, the Shanghai Port-Inland Terminal Container Logistic Tunnel, and the Shanghai Underground Waste Collection and Transfer System, are either constructed underground or an underground alternative is being considered [43]. Another recurring theme related to UUI is the upgrading of infrastructure in urban regeneration projects (Target 9.4). In general, UUI is the only alternative to the upgrading of infrastructure or the setup of new facilities in old urban centers. Exemplary cases include the upgrading or completion of an urban transport system [39], the renewal or expansion of utility networks in Pamplona, Spain [50], airport expansion in Shanghai [49], and the upgrading of a goods mover system in Singapore [51].

6) SDG 11: sustainable cities and communities. SDG 11 could be the leading goal with the most evident contributions of UUS use. Therefore, these contributions are addressed separately below.

- Target 11.1. The concern of housing can be influenced by UUS use both directly and indirectly. Directly, UUS can be used for living, which was once a ubiquitous tradition dating back to the origin of human beings. However, this tradition is losing popularity in modern society because, after all, it is notoriously difficult to create a suitable longterm living environment for humans, which is reflected by the deeply rooted negative perceptions of people toward underground housing [52]. Nowadays, underground living in urban areas occurs only under harsh conditions such as extreme climate or unaffordable house prices. Coober Pedy, Australia, is one of the few true underground cities. The residents of this settlement, numbering less than 2000, are all opal mining workers who work and live underground to escape the scorching desert climate. Beijing, China, is well-known for its underground rental housing market, where low-income, often rural migrant workers, choose to live [53]. In recent years, however, the local housing department began to regulate this market, stipulating that only the first underground floor with a residential permit can qualify for renting. In general, it appears that UUS is not suitable for direct housing. However, the indirect value of extra land freed up by UUS use can be substantial for providing adequate housing.

- Target 11.2. UUS has been actively used to optimize urban transport systems in central business districts, particularly in terms of completing expressway networks, implementing rail transit facilities, increasing parking capacity, and separating pedestrians and motor vehicles [54]. In addition, underground rail transit systems have been studied to be incorporated into urban logistics systems during off-peak periods, offering the advantages of safety, punctuality, reliability, and low emission [55].

- Target 11.3. For this target, UUS, specifically UUI, mainly contributes to inclusive urbanization enhancement.
Various reasons could lead to circumstances in which certain groups of individuals feel excluded from social progress. For instance, social exclusion can occur, largely because of land scarcity, in undeveloped historic areas, neighborhoods with nearby nuisance facilities such as sewage treatment works, and even in cities where people feel disrespected because they are forced to dig out their deceased relatives to make room for urban development. To address these issues, Pamplona, Spain, refers to urban utility tunnels to adapt the historic area to the emerging social needs [50]. Hong Kong, China, decided to move the Sha Tin sewage treatment works into a nearby hillside to alleviate people's "Not-In-My-Backyard" sentiment [44], while Jerusalem, Israel, constructed an underground cemetery to show respect to the deceased [56].

- Target 11.4. As mentioned above, cultural heritage is a critical underground asset that should be seriously protected and safeguarded. When uncovered during excavation, underground heritage can seek underground space use for conservation and exhibition purposes, as is well demonstrated by the case of the "Emperor's Chariot Drawn by Six Horses" Museum in Luoyang, China [57]. Additionally, the visual pollution caused by overhead electric cables can be significantly reduced, and the traditional landscape of historical heritage can be well preserved by placing this nuisance underground.

- Target 11.5. Resilience is a major concern in urbanization. UUS is regarded as capable of enhancing many aspects of urban resilience because of the isolation provided by the covering soil or rock [58], which provides good protection from catastrophic events such as air raids, hurricanes, floods, external fires, and external radiation for both humans and goods and significantly reduces ground motion caused by earthquakes and explosions. Admiraal and Cornaro [59] examined the role of UUS in achieving urban resilience from the perspectives of providing and enhancing protective natural and man-made assets, ensuring the continuity of critical services, and providing reliable communication and mobility. The mitigation of direct economic losses caused by explosions is among the key factors for Singapore to develop underground ammunition storage [51]. In addition, UUS can act as a complementary discharge channel for pluvial flooding, as exemplified by the Stormwater Management and Road Tunnel (SMART) in Kuala Lumpur, Malaysia and the Metropolitan Outer Area Underground Discharge Channel in Tokyo, Japan.

- Target 11.6. The contributions of UUS to air quality enhancement have been summarized in SDG 3, with the other focus of this target being waste management. In this respect, UUS is widely used to construct wastewater treatment plants, such as that in Viikinmäki, Finland [60]. In addition, according to the statistics provided by Hidalgo et al. [61], nearly a thousand vacuum systems for solid waste collection are in operation all over the world. Another potential contribution from UUS use not only to 
the environment but also to the economy is the sustainable management of excavated geomaterials such as soil and rock in urban areas. Magnusson et al. [62] documented that compared with the use of quarry materials, the recycling or reuse of geomaterials can significantly reduce $\mathrm{CO}_{2}$ emissions and decrease material handling costs by $85 \%$. The 2015 statistics of Japan show that $51 \%$ of the total excavated soils was reused at the same site and $49 \%$ was transported and stored for future use, e.g., for the construction of road bases and embankments, river dykes, backfills, elevated land, and reclamation [63].

- Target 11.7. In many built-up historic districts, the lack of public spaces due to land scarcity is a common but pressing problem for urban regeneration that can potentially be solved through UUS use. UUS can be used directly to create public spaces such as swimming pools, sports hall, art centers, theaters, museums, shopping malls, etc., which is general practice in Finland [60], Norway [64], Japan [65], and Canada [66]. The competitive edge of underground open space is that it can let people avoid the traffic noise and bad weather [67]. The other way to reach this target is to relocate surface or aboveground facilities underground and free up surface land for open public spaces. The most well-known case is the Central Artery/ Tunnel Project (CA/T) in Boston, USA, commonly known as the Big Dig, which released 30 acres of new open green space in the downtown area [68].

7) SDG 12: responsible consumption and production. As summarized in Section 2.2, UUS comprises multiple assets, both natural and artificial, that are closely related to urban sustainability. Therefore, the sustainable consumption and management of underground assets (Target 12.1 and 12.2) is a compulsory part of this goal. With respect to waste management, attention should be paid not only to the recycling and reuse of excavated geomaterials, but also to the abandoned UUI, in which the designed functions cannot meet the changing social needs (Target 12.4 and 12.5). As a valuable social asset that can hardly be rehabilitated or removed, these facilities can be adapted to other purposes such as parking, storage, and public parks (see the Lowline Project [54]), based on current and future needs and demands.

8) SDG 13: climate action. As summarized above, UUS can provide discharge channels for flash floods and shelters to escape extreme weather caused by climate change (Target 13.1). Moreover, UUS use can, to some extent, reduce the carbon emissions of a given area from the perspectives of transportation, land use, building energy consumption, and geothermal energy use. This potential has been well demonstrated by UUS use in Shanghai Hongqiao CBD Phase I, which is an important pilot project for the development of a low carbon community [69]. Yang et al. [70] set up a framework to theoretically examine the positive influence of UUS use on urban microclimates (Target 13.2). This framework employs the microclimate simulation software Envi-met to quantitatively compare the indicators of temperature, humidity, wind, $\mathrm{CO}_{2}$, and mean radiant temperature between surface parking and underground parking (with green surface coverage).

9) SDG 15: life on land. UUS is the natural habitat of multiple fauna and flora members as well as microorganisms, all of which are important components of biodiversity and engage in activities with a profound impact on the environment [71]. Thus, the conservation of UUS for underground organisms helps to hinder the degradation of natural habitats (Target 15.5).

\subsection{Potential damages}

\subsubsection{Damages to UUS assets}

As pointed out by Sterling et al. [28], UUS is an environmental entity and a natural resource in its own right. The UUS assets contributing to SDGs are inhabited in the soils and rocks constituting the underground system. The potential of these assets largely depends on the properties of the soils and rocks, which, however, can be damaged by any form of underground activities such as the aforementioned UUS uses. This signifies that when a city utilizes UUS to deliver SDGs, it also introduces detrimental damages to some or all UUS assets and thus indirectly compromises urban sustainability [29].

Qiao et al. [29] summarized the potential damages to UUS assets ensuing UUI development, which can be adapted to explain the potential damages to UUS assets, as listed in Table 4 and shown in Fig. 1.

\subsubsection{Damages to urban functioning}

\subsubsection{Security and safety (Targets 11.5 and 11.7)}

Even though UUS is advantageous for the mitigation of external disasters, most UUI types, such as underground metro facilities and underground shopping malls, are vulnerable to internal disasters, including fires, blasts, radiation, and internal flooding [58]. If they are well interconnected with other adjacent underground facilities, which is generally considered as an exemplary design ideology, the disaster-induced risk increases [3]. For this reason, in the 1980s, Japan began to regulate and limit the expansion of interconnected underground pedestrian networks [65].

In addition, Bobylev [23] showed that underground pedestrian crossing tunnels, particularly long ones, can attract criminals, suggesting that commercial facilities and closed-circuit television cameras should be allocated within these tunnels to increase their exposure and thus reduce crime. 
Table 4 Potential damages to UUS assets due to UUS use (according to [29])

\begin{tabular}{|c|c|}
\hline assets & detailed aspects \\
\hline physical space (UUI) & $\begin{array}{l}\text { - UUI structures need a buffer zone to preserve the } \\
\text { force equilibrium. The potential of UUI use, } \\
\text { particularly in shallow underground, is compro- } \\
\text { mised by geothermal and groundwater use facilities } \\
\text { and the need to protect underground historical } \\
\text { heritage and organisms. } \\
\text { - UUI deformation occurs because of localized } \\
\text { groundwater leakage [72]. }\end{array}$ \\
\hline
\end{tabular}

geothermal energy

- The thermal properties and mass of soil and rocks are altered by loss of UUI use [73] and groundwater use [74].

- Geothermal environment changes because of groundwater use and UUI operation [75].

groundwater

geomaterials

historical heritage

space continuum

underground organisms

- The habitats of underground organisms may be destroyed by all sorts of UUS uses.

- The living environment of underground organisms may be altered by the construction of UUI, and the exploitation of geothermal energy and groundwater [85].

\subsubsection{Health and well-being (Target 3.9)}

The confined space of UUI makes it very difficult to ensure air flow and exchange with the surface. Cui and Nelson [89] documented the air pollution problems of underground transport facilities in their synthesis, probing the concentration of PM and dust in metro facilities and the concentration of exhaust emissions such as carbon monoxide (CO), PM10, and VOCs in underground car parks.

The lack of natural light is another problem associated with UUI users. Qiao et al. [29] compared the health perspectives of artificial and natural lighting, illustrating that staying underground for a long time adversely affects blood circulation, hepatic function, and bone health.

Other problems such as humidity, disorientation, and fear of entrapment are also frequently documented in UUS research $[90,91]$. These problems not only give UUI users unpleasant feelings but even damage their health, which eventually reduces people's willingness to use underground facilities.

\subsubsection{Upgrading capacity (Target 9.4)}

In general, UUI structures require a buffer zone to maintain the force equilibrium. This implies that, regardless of the vertical dimension, UUS is more easily congested than surface. In effect, most of the urban shallow underground is faced with space shortages due to the increasing amount of scattered utility pipelines [92], which complicates the use of UUS for urban redevelopment. Moreover, the existing UUI structures are very difficult to expand or remove [28] to accommodate newly emerging urban needs. Thus, low and limited upgrading capacity may hinder future urban redevelopment.

\subsubsection{Public space vitality (Target 11.7)}

With the development of underground rail transit systems, underground pedestrian systems are becoming more attractive for key urban areas (e.g., CBD) owing to their overall efficiency and convenience [93]. However, in their Hong Kong case study, Zacharias and He [94] put forward a concern that this benefit may come at the price of street vitality to orient pedestrians from the surface to the underground, which is a potential threat to the local economy.

More directly, the discoordinated entrances of UUI, such as the underground shopping arcade in Shenyang, China, may encroach pedestrian walking and activity space and even damage the traditional landscape [95].

\subsection{Collaborative approach needs}

The realization of SDGs by 2030 is not an easy task, as multiple instruments and measures are required to guarantee vision implementation. For this reason, a number of instruments and measures, from the perspectives of planning, policy, institution, organization, and partnership, are included among the detailed targets of SDGs. This is also the case when UUS is used to facilitate SDGs. As revealed by many studies, UUS is a complex 


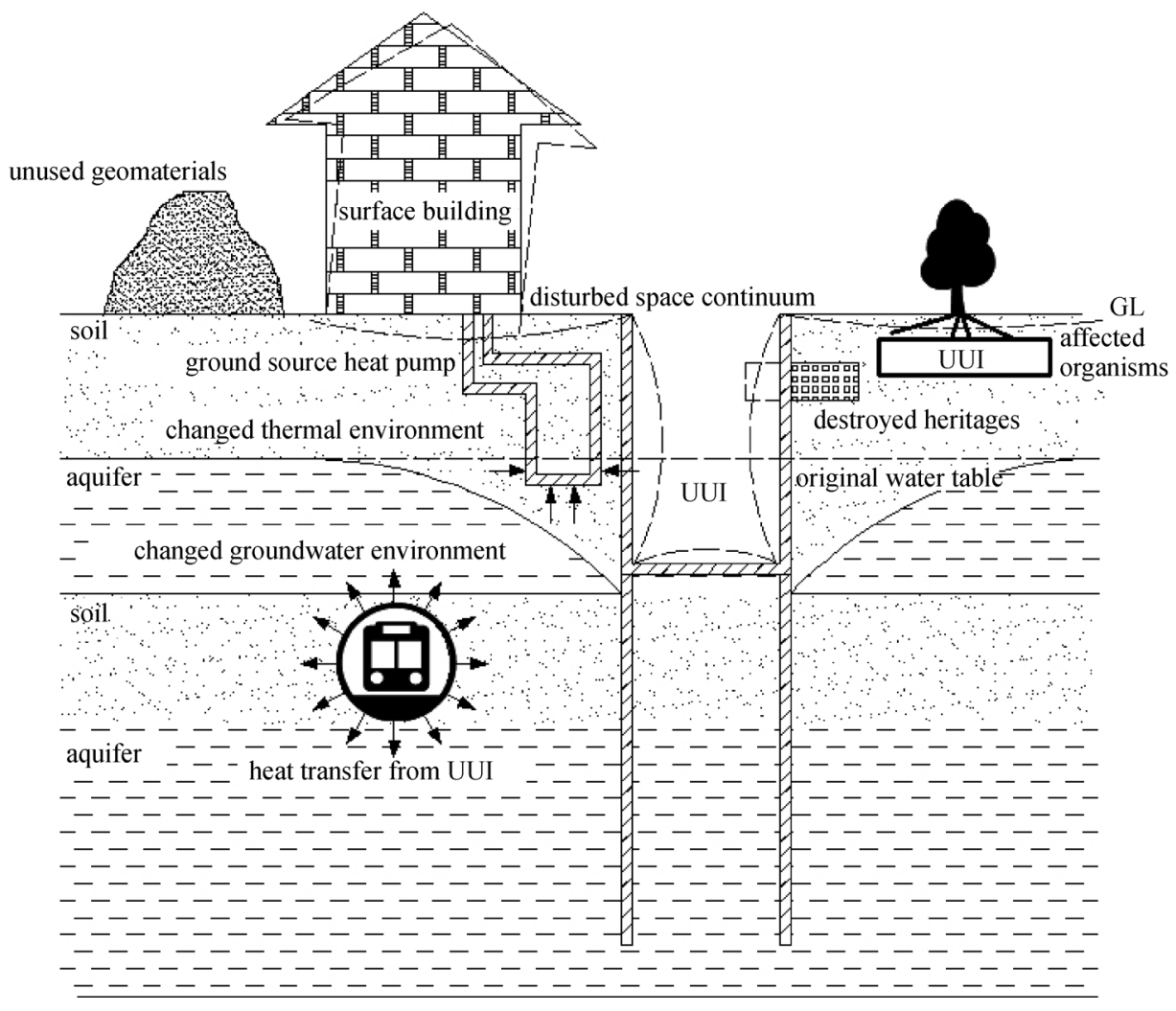

Fig. 1 Schematic representation of potential damages to UUS assets due to UUS use.

system comprising various underground assets that contributes to SDGs in multiple ways while also posing potential threats to their realization. Therefore, the primary objective of UUS use can be articulated as maximizing the related benefits and minimizing the related damages without compromising the ability of future generations to use UUS to meet their own needs.

To this end, considerable effort is required. SDG targets provide good references for such efforts, which also apply to UUS development. These targets, such as Targets 12.8, 16.10 , and 17.18 , underline the importance of high-quality, timely, and reliable data and accessible information, which also assists the participation and awareness-raising of the general public (Targets 11.3, 12.8, and 16.7) in UUS development. Meanwhile, SDGs also require effective, accountable, and transparent institutions with coherent policies, strategies, and plans (Targets 11.3, 11.B, 13.2, and 17.14) and relevant measurements (Target 17.19) toward UUS use and development. From a disciplinary perspective, these efforts can be achieved primarily by land administration and integrated planning, which should help to achieve synergies and avoid conflicts among the uses of various UUS assets to the extent possible.

However, additional efforts are needed to alleviate potential damages to urban functioning. In this respect, architectural measures can assist in mitigating disasterinduced losses, creating a friendlier and healthier environ- ment, and harmonizing the interfaces of underground and surface facilities. To facilitate UUS development in an increasingly congested and complex underground built environment, more advanced construction technologies are necessary.

This analysis leads to the conclusion that the facilitation of UUS use to realize SDGs requires at least the integrated efforts of the four multi-disciplinary sectors of land administration, planning, architecture, and construction. The coordination of these sectors requires a collaborative approach. However, each sector itself is a complicated dimension, as shown in the following section. Therefore, one should thoroughly appreciate the requirements of the four sectors so that they can be better factored and embedded in the collaborative approach.

\section{Critical dimensions for the collaborative approach}

\subsection{Modern land administration}

In most countries, the underground world is still in chaos, partly because of the insufficient amount of available underground data, including not just geotechnical data but also data pertaining to existing underground infrastructures, as emphasized in SDGs. In some cases, UUI 
construction may have to be paused to deal with the uncovered heritage or the collided underground facilities. Even in the planning stage, highly beneficial UUI projects such as large-scale transportation tunnels may be called into disputes over encroachment on private property, as surface land owners claim that the underground space below their feet is their vested interest attached to the land [96]. As such, legal ambiguity is a major issue for UUS development. Considering that UUS assets are deeply concerned with urban sustainability, which is truly a public interest, securing reasonable and deliberate use is also an important issue for SDGs. To a great extent, the availability of these data and the absence of legal issues are the prerequisites for the other three dimensions. In this respect, a modern land administration system can address the issues related to land tenure, land value, land use, and land development [97]. When it comes to underground issues, however, there are still some problems confronting modern land administration.

\subsubsection{Legal issues}

Legal issues are fundamental and critical for UUS development. The rights, restrictions, and responsibilities over aboveground and underground areas lie at the heart of modern land administration and are often shortened to RRRs. Land valuation is another issue closely related to RRRs and another focus of modern land administration.

\subsubsection{RRRs of UUS}

The most fundamental issue for the RRRs of UUS is the ownership of UUS, or the land use rights for nations such as China wherein all land belongs to the state. This issue stems from the long-standing traditional doctrine that land ownership extends from the depth of the earth to the height of the sky [98]. However, the demand for aviation development has driven most legal systems to restrict air rights. On the contrary, the restriction of underground rights is not that pervasive. However, it becomes an inevitable issue to deal with when alleviating land use pressure and supplementing infrastructure facilities in a densely developed urban environment, as UUS in most cases is the only alternative. More often than not, the underground routes will go under private or alienated land to raise the aforementioned disputes.

To resolve this issue, the legislation should clarify UUS ownership status and the extent to which the owner can dispose of the UUS. As mentioned before, the space continuum is a valuable UUS asset to support surface buildings, which can also be affected by UUS development. Therefore, a certain amount of UUS must be attached to the surface land. In other words, the ownership of surface land should extend to a certain downward depth. However, the objective of addressing this issue is to make the UUS under private land viable for public welfare. It is apparent that the ownership of UUS should be identified as a separate property unit [98], which means that UUS below the same land can be owned by different interest holders at different depths. For example, the Civil Code of the People's Republic of China (2020) states that underground rights and air rights can be independent of surface land use rights [99].

It then comes naturally to critical depth determination. However, the decision on whether it is practical to establish a fixed downward limitation on UUS ownership remains controversial [98], as the required volume of supporting and developed space depend on geotechnical conditions (such as soft clay and hard rock) and land use purposes (such as high-rise complex building and low-rise residential building), which are dynamic over time [100]. For countries without a fixed downward limitation, UUS ownership is generally extended to the depth where UUS can be "reasonably necessary" below a minimum disposal depth (i.e., $6 \mathrm{~m}$ for agriculture, $10 \mathrm{~m}$ for building, and $15 \mathrm{~m}$ for industry, Malaysia [100]), or has "no interests in exclusion" (Germany), or a "plausible interest can be manifested" (Switzerland) [96]. In practice, however, these stipulations lack manageability and often make judgment time-consuming, particularly in countries with wide UUS use. Therefore, some countries or regions place fixed downward limitations on UUS ownership, either in laws or land titles or subdivision plans, to guarantee the accessibility of the remaining UUS under private surface land. For instance, Japan stipulates that UUS in the three metropolitan areas (Greater Tokyo, Kinki, and Chubu) is for public use starting from 40 or $10 \mathrm{~m}$ below the bearing layer of foundation piles [28]. On a similar note, Singapore adopts $30 \mathrm{~m}$ [51], while Northern European countries such as Denmark, Finland, and Norway tend to adopt $6 \mathrm{~m}$ as the lower depth of private ownership [96]. The subdivision plans in Victoria, Australia, usually specify a depth limitation [101] of 50 feet, which equals $15.24 \mathrm{~m}$.

The restrictions and responsibilities should be specified in land titles to ensure that UUS assets can be reasonably used for SDGs. Even though the clarification of UUS ownership ensures the prospects of developing UUI (physical space) under private land, the land owner of the UUS should be held responsible for damage to the existing UUI and the surface buildings and maintain the properties of the space continuum. In particular, a buffer zone of soils and rocks should be reserved, not just for the self-owned UUS, but for the adjacent UUS, to maintain the force and displacement equilibrium of UUS structures. The use of shallow geothermal energy, which is beneficial for SDGs, should be encouraged. However, permission to use groundwater should be given with caution, as the extracted groundwater can come from far beyond the private UUS, and the unrestricted extraction may lead to global issues such as portable water shortages and land subsidence. Moreover, the water seepage path should be guaranteed. 
Most countries claim geomaterials (including oil, gas, coal, metal, and minerals) and historical heritage to be public property that is, therefore, not accessible to private UUS owners. As in the case of surface land development, one is less likely to let the UUS owners take charge of protecting underground organisms.

\subsubsection{Land value}

With the establishment of separate underground ownership, a new land market is emerging beneath the urban area. Many developers have begun to seek profitable opportunities by investing in underground shopping arcades, underground car parks, underground sports, or recreational facilities. However, the land market for UUS is far from being mature. For instance, most Chinese cities set the underground land price as a certain proportion of surface land price, for example, $50 \%$ for the first underground layer, $25 \%$ for the second, and $12.5 \%$ for the third. Obviously, this pricing is too rough to reflect the real value of underground land, which may eventually result in UUS waste. To fill this gap, Pasqual and Riera [102] employed the shadow price method to derive underground land value from parameters such as land price, construction cost, and profitability of UUS development. Other researchers [103106] took various variables such as land use, population, transport, location, policy, and socio-economic variables into account of the extensively used hedonic pricing method. Under the assumption that the current land market does not capture the real land price of UUS, it seems that neither the shadow price method nor the hedonic pricing method can meet the requirements of land valuation in modern land administration. A plausible valuation technique incorporates the net benefits (equaling total benefits minus total costs) into underground land prices [107]. However, it is necessary to evaluate whether the external benefits and losses derived from UUS use should be integrated into the underground land value to offset the risks of compromising SDGs.

\subsubsection{Registration of underground land tenure}

Turning the underground chaos into order requires the proper registration, that is, the systematic data recording, of underground land tenure. A cadaster, i.e., a comprehensive register of spaces delineated by geometry and topology to which a certain record of RRRs is attached [108], is an underpinning instrument in modern land administration systems [109]. Therefore, after the establishment of a separate underground ownership mechanism, the cadastral system of a city should begin to integrate the RRRs of UUS along with the geometry and topology. Nevertheless, few attempts have been made in this direction, as the delineation of UUS ownership requires a third dimension, that is, the downward dimension, whereas the current cadasters across the globe are two-dimensional (2D) systems unable to implement UUS registration in a three-dimensional (3D) manner [109,110]. In particular, 2D cadaster systems can hardly deal with a scenario where several UUS owners share the same projected footprint on the surface or their UUS ownerships intersect with each other in a $2 \mathrm{D}$ representation.

The key to the registration of underground land tenure is the 3D cadaster system, which is a much-discussed topic in modern land administration. Currently, many countries and regions such as Victoria, Australia [111,112], Shenzhen, China [110], Malaysia [113], Singapore [114], and Korea $[109,115]$ are conducting research and development to implement 3D cadastral systems. Shenzhen and Korea even did preliminary research on underground 3D cadasters but failed to address the aforementioned legal issues. Even though modern land administration practices differ from one jurisdiction to another, mainly in legal processes and legal information, they do have some common technical issues to address, as summarized below.

\subsubsection{Technical issues for underground 3D cadasters}

\subsubsection{Requirements for underground 3D cadasters}

According to Atazadeh et al. [116], the requirements for 3D cadaster systems, which are referred to as 3D RRR management in their study, are 3D legal data and 3D physical data. Legal data comprise legal interests and legal boundaries [101], with legal interests further classified into primary and secondary ones. Primary legal interests do not allow any overlaps or gaps between legal spaces that define the geometrical extent of these interests, while secondary legal interests impose administrative conditions over primary legal interests. Rajabifard et al. [101] considered Victoria, Australia, as an example to illustrate the possible spatial configurations of legal interests, which in the Victorian case include lot, common property, road, and reserve for primary legal interests, and easement, restriction, depth limitation, and airspace for secondary legal interests. Legal boundaries are delineated to unambiguously define the spatial dimensions of primary legal interests [116,117]. Legal boundaries can be formed either by observable elements (e.g., structures, ambulatory creeks or coastlines, and projections) or by fixed and precisely surveyed measurements. Physical data for surface 3D cadasters include building elements (e.g., walls, floor slabs, ceilings, and columns), distribution elements (e.g., ducts, conduits, electricity cables, drainage, and water supply), and geographic elements (e.g., roads) [116].

As an important component of 3D cadastral systems in urban areas, underground 3D cadasters are also subject to the aforementioned requirements. However, when applied to the UUS scenario, these requirements may face some distinguishing characteristics that need special considera- 
tions, as listed in Table 5.

In the foreseeable future, the primary legal interests of an underground 3D cadaster will include lot, common property, and reserved public space. In particular, a "lot" of UUI in the underground 3D cadaster system is a volumetric lot (incorporating the requirement of depth limitation) that normally consists of two main parts, namely the underground body of leased ownership and the corresponding accessory facilities such as exits/entrances, ventilation shafts, and light wells. If UUS ownership is isolated and separated from surface land ownership, the installation of accessory facilities will require the easement from the adjacent surface and underground land owners. Meanwhile, the easement within the UUS lot should be made explicit regarding whether it is permitted to let the utility facilities of the relevant referral authorities (usually utility companies) to go through the lot. As stated before, restrictions on the use of UUS assets should be imposed on UUS ownership, and responsibilities and liabilities should be stated clearly to prevent possible damages to others' assets. Common properties refer to volumetric spaces or structures that are shared by multiple underground ownerships, such as walls, ceilings, and slabs between two adjacent underground shopping malls. Except for lots and common properties, the rest of the UUS is defined as reserved public space that can be leased in the future or used for public welfare. As the spatial scope of a UUI structure is generally smaller than the ownership body, the legal boundaries of UUS ownership are more likely to be formed by fixed and precisely surveyed measurements to reserve enough space for the balance of both the structure itself and other adjacent structures.

The requirements of underground 3D physical data are also different from those of surface 3D data. For underground 3D cadasters, geographic elements are no longer necessary. Instead, stratum elements should be created to represent the reserved public space and parts of leased lots as well as the geological properties of soils and rocks. The requirements for building and distribution elements are the same as those of the surface 3D cadaster.

\subsubsection{Potential solutions for 3D underground cadasters}

As stated above, the fundamental requirements for a $3 \mathrm{D}$ underground cadaster are legal data and physical data. To meet these requirements, data models should be compatible with and practicable for the realization of modern land administration systems. The various 3D data models developed over the past decade can be broadly categorized into purely legal data models, purely physical data models, and integrated data models [101]. The most widely used purely legal data model is the Land Administration Domain Model (LADM), which is an international standard and a common language for land administration [118]. Kim and Heo $[109,115]$ adopted LADM to develop a 3D underground cadastral data model for the current Korean land administration system. However, LADM models spatial objects using a multi-surface approach that is not sufficient for visualization, computation, and analysis [97], which are required in the other critical dimensions of UUS development, such as planning, architecture, and construction. Moreover, LADM is not adequate in defining legal objects through semantic information [117], which is necessary for distinguishing physical boundaries between adjacent UUS ownerships. On the contrary, purely physical data models such as CityGML (GML = geography markup language) and IFC (Industry Foundation Classes) are incapable of dealing with legal interests.

The deficiencies of purely legal and purely physical data models can be mitigated using integrated data models [101] such as the LandInfra (Land and Infrastructure) model and the integrated model of CityGML and LADM or extended physical data models such as those obtained by extending the IFC model with semantic connectivity relationships defined between legal spaces and physical elements $[97,116,117]$. However, none of these integrated models have been examined in the UUS scenario. It may appear that the LandInfra model is more suitable for an underground $3 \mathrm{D}$ cadaster, as it is designed to model infrastructure facilities such as roads, rails, and drainage

Table 5 Requirements for underground 3D cadasters

\begin{tabular}{lccc}
\hline categories & sub-categories & requirement & examples \\
\hline 3D legal data & legal interests & & - \\
primary legal interests & volumetric lot & elevators, walls, slabs, utility pipelines \\
& common property & - \\
& recondary legal interests & easement & utility pipelines \\
3D physical data & restriction & underground assets \\
& legal boundaries & fixed boundary & - \\
& stratum element & walls, windows, doors, slabs \\
& & building element & utility pipelines, electricity cables
\end{tabular}


and water distribution systems. However, as analyzed in the paper, UUS is a complex system that is far more than infrastructure facilities. Therefore, the suitability of these and newly created models or any new combinations needs to be further demonstrated.

\subsection{Integrated planning}

UUS seems to be disregarded or undervalued in the planning system of most cities worldwide. Instead, UUS is often involved in scattered sectorial planning, notably in the infrastructure utility, water, and energy sectors and is therefore not coordinately conceived and sufficiently planned in urban development [119]. Moreover, the concept of UUS in urban planning tends to be confused with UUI. For this reason, the authors argue that even though UUS is incorporated in urban planning, only one out of seven UUS assets is considered, while the others are left out. These factors may compromise the potential of UUS contributions to SDGs.

As the importance of UUS use in urban sustainable development becomes gradually recognized by academia, researchers argue that UUS should be integrated into urban planning and policy systems $[23,120,121]$. However, the planning industry rarely handles UUS very delicately. This neglect is partly due to the traditional 2D intuition among planning practitioners, who tend to disregard or undervalue the third dimension beneath the map they are working on, and is partly caused by the complexity of and the unfamiliarity with the invisible underground world, with planning practitioners having little idea of what can be used underground and where.

UUS planning is different from conventional land use planning in the following respects. The most evident distinction is that UUS planning is truly $3 \mathrm{D}$ planning. This is endowed by the media of soils and rocks, which can support underground structures at various depths. Conventional land use planning can deliver partial 3D solutions, as exemplified by viaducts required for road crossings [122]. However, the surrounding soils and rocks make it nearly impossible to return the underground environment to its original state [28], which means that UUS planning is in effect a one-off action, the implementation of which cannot be rehabilitated as easily as that of surface actions $[123,124]$. In addition, the benefits derived from UUS use (called externalities) are largely out of market. The presence of externalities usually places UUS solutions at the center of debates over construction costs much higher than those encountered for surface or elevated structures [125]. These characteristics indicate that UUS planning needs to be well-grounded, notably for effective planning technologies, including, but not limited to, suitability evaluation of UUS use, demand forecast, layout methods, and cost-benefit analysis.

\subsubsection{Planning technologies}

\subsubsection{Suitability evaluation of UUS use}

The results of the suitability evaluation of UUS use answer the question of what types of assets the UUS at a given spatial location can supply to a city. Suitability evaluation should investigate the conditions of various UUS assets, that is, physical space, geothermal energy, groundwater, geomaterials, historical heritage, space continuum, and underground organisms, and evaluate the potential of UUS exploitation at every location within the confines of an urban area. Multiple efforts have been made to evaluate the so-called UUS resources, including physical space, geothermal energy, groundwater, and geomaterials. Some works, principally those from the Deep City Project $[4,26,27,126,127]$, consider the four UUS assets comprehensively, while others deal with only one or two (mostly on physical space [128-131]) of the four UUS assets. The recent work of Price et al. [132] incorporated the UUS asset of space continuum into the framework of ground-use optimization. For the other UUS assets, that is, historical heritage and underground organisms, the amount of devoted evaluation works remains limited.

The general methodology adopted in existing literature to evaluate the suitability of UUS use is multiple-criteria decision analysis, which features fuzzy set theory and an analytical hierarchy process (AHP). The differences between these methods usually reside in the selection of indicators, weights, and criteria. The problem with this methodology is that the determination of weights and criteria can be too subjective to change the evaluation results, which are sometimes in line with private-sector economies. The evaluation process is typically undertaken on a geographic information system (GIS) platform, which can facilitate the overlap of multiple indicators via certain algorithms and spatially show comprehensive results. However, the process and the corresponding results are usually simplified into $2.5 \mathrm{D}$, that is, the third dimension of UUS is separated into several depth intervals (e.g., 0 to $-10 \mathrm{~m},-10$ to $-30 \mathrm{~m},-30$ to $-50 \mathrm{~m}$, and deeper than $-50 \mathrm{~m}$ ). Each interval is treated as a uniform space in the evaluation process. Therefore, it is clear that the treatment lacks precision and cannot provide accurate evaluation results if UUS is used within the interval.

In terms of historical heritage and underground organisms, the evaluation process is more directly linked to the investigation results, being a problem of "yes or no" rather than that of "good or bad".

\subsubsection{Demand forecast}

The results of the UUS demand forecast answer the question of what and how much a city demands from UUS 
for sustainable development. This process comprises the forecasting of the types of UUS use and the amount of each type. The demand for UUS is location-specific, i.e., is contingent upon the socio-environmental-economic conditions of the targeted area.

The most frequently used approach to forecast the types of UUS use is the comparison method [133], which basically follows the exemplary cases of UUS use in other cities or countries with similar socio-environmentaleconomic conditions [134]. However, the problem of this method is that there would be no existing UUS cases to refer to someday in the foreseeable future when urban development experiences cannot match the newly emerging urban development needs. To this end, future scenario analysis is necessary. Xie et al. [135] presented a strategic concept of an "underground ecological city" in which UUS was proposed to be used down to $2000 \mathrm{~m}$ below the surface. The concept is bold and ambitious but needs to be further reasoned and justified.

The UUS demand is considered to be influenced by various factors that can be totally distinctive in different studies. For instance, Peng et al. [136] adopted the factors of land price, land use index, floor area ratio, passenger flow rate, and transfer line number to quantitatively analyze the amount surrounding metro stations in Osaka. He et al. [137] adopted the factors of population density, GDP, and real estate price for the case study of Shanghai. The regression analysis of these factors showed that distinctive models can be obtained, which means that the results are strongly dependent on the type of data set and mathematical model selected for regression. A plausible solution is the use of artificial intelligence technologies such as machine learning to derive the relationship between the UUS amount and numerous factors related to UUS development.

\subsubsection{Layout methods}

There are no specific methods for the layout of UUS use. Similar to traditional urban planning, the planning "mind set" is to strike a supply-demand equilibrium of urban sustainable development via UUS use. However, as this strategy inevitably results in potential conflicts among UUS assets, the other important point for the layout of UUS use is the minimization of potential conflicts by promoting synergies among UUS assets. For instance, the use of physical space, geothermal energy, geomaterials, and space continuum can be synergized if the relevant facilities can be well planned and technical problems can be addressed.

Currently, most layout works in UUS planning are conducted manually based on the results of suitability evaluation and demand forecast. This means that future synergies among UUS assets rely largely on the rigorous- ness of UUS planners. Given that UUS is a complex system, human-caused careless mistakes seem to be inevitable in the process of comprehensive UUS planning, posing serious risks to urban sustainability. To lower the potential risks, artificial intelligence can be applied in the process of UUS planning.

\subsubsection{Cost-benefit analysis}

Admittedly, the construction costs of UUS projects are generally much higher than those of equivalent surface or elevated projects [125] and cannot be compensated by the direct benefits realized through the market. On the other hand, the highly advocated socio-environmental benefits derived from UUS planning are not fully reflected in the market and are the main factors impeding the promotion of UUS use [138], largely because the descriptive external benefits cannot convince decision-makers to invest substantial funds in UUS development. This is the main thrust for the monetary valuation of external benefits for UUS projects and planning. When evaluating the external benefits of UUS planning in monetary terms, one should not lose sight of the negative effects of UUS development, which is necessary for a well-grounded cost-benefit analysis incorporating the external influences of both positive and negative effects. Such a cost-benefit analysis can also be used to compare different UUS solutions from the perspective of maximum net benefit.

The methods employed in existing literature for the monetary valuation of UUS uses include the contingent valuation method (CVM) [139,140], the hedonic pricing method (HPM) [103], and the replacement/restoration cost method (RCM) [29-31]. However, these studies only deal with UUI while leaving out the other UUS assets. In addition, these methods also have intrinsic problems when applied to the UUS context. CVM is sensitive to the familiarity of respondents with the UUS assets, HPM requires a sound UUS market, and RCM is influenced by the listing of evaluated items and the proxies used for monetary values. At the present stage, these methods can only provide a relative magnitude for reference and comparison.

\subsubsection{Planning levels and focuses}

UUS use should be streamed into various phases of urban planning. Helsinki is probably the most well-known case worldwide for its UUS planning, that is, the Underground Master Plan of Helsinki [60]. On a similar note, many cities are also paying due attention to UUS planning, as data show that $\sim 150$ out of 341 prefecture cities in China have completed or are preparing for UUS planning [122]. In effect, the most ideal solution is to consider UUS and surface space simultaneously in the same planning 
documents. However, the reality is that many urban planners still have little idea of what to do with UUS. Therefore, many cities have to prepare UUS and surface planning separately and combine them afterwards.

Even though planning practices differ from one jurisdiction to another, especially in terms of planning systems, there are at least two levels into which UUS planning should be integrated as a key supporting component of SDGs.

\subsubsection{Master planning}

Master planning orients a city toward SDGs in a certain future period. As an important contributor to SDGs, UUS should be definitely integrated into urban master planning [141]. In practice, however, most UUS planning cases deal with only one or two UUS assets, principally regarding the use of UUS physical space to accommodate various urban needs while safeguarding the space continuum. Some historic cities, such as Luoyang, China, considered the balance between the development of urban space and the conservation of historical resources [95]. Obviously, there is still much work to integrate all essential UUS assets into UUS planning practices. From the viewpoint of SDGs, the master planning for UUS use should include at least the contents from the following perspectives [122]:

- lay out priorities and strategies for UUS development;

- identify the types of UUS use and the amount of each type;

- determine the suitable areas and depths for various types of UUS use;

- delineate the areas and depths for the conservation of UUS assets;

- propose modes for synergized use of UUS assets;

- arrange time sequences for the planned major UUS projects.

\subsubsection{Regulatory detailed planning}

Regulatory detailed planning is a specific term in the Chinese planning system, resembling zoning plans in other jurisdictions and being a statutory and contractual instrument for guiding and regulating developers' behaviors in the use of UUS, notably underground physical space, in urban key areas [93]. Examples with and without detailed regulatory planning for UUS use have shown that such planning is pivotal in shaping high-quality UUI with overall land use efficiency, vehicular and pedestrian accessibility, and a low-carbon environment [142]. Moreover, it would be helpful in protecting the UUS assets related to social welfare in the alienated area.

According to the study of Peng et al. [93,143], regulatory detailed planning for UUS use should at least adopt the indicator framework regarding land use and development volume, spatial designs and guides, ancillary facilities, activities, and management issues. For the key indicators that are closely related to the overall efficiency and safety of the planned area, such as depth, elevation, inter-connection, and exit/entrance, mandatory regulations should be applied. Other indicators, such as function, story height, and interior decoration style, can be set as guiding indicators given that they are more concerned with the developers' own interests.

\subsection{Architectural design}

As analyzed above, architectural design is crucial for creating a friendlier and healthier environment for underground users, mitigating internal disaster losses, and harmonizing the interfaces of underground and surface facilities, which are important aspects of SDGs. More importantly, large-scale UUI facilities without good architectural design will cause a great waste of UUS assets, as they tend to become less attractive for residents and will finally be abandoned with little chance of rehabilitation. For instance, the well-known exemplary case of UUS use in La Défense is now being re-considered as "malfunctions" because it is treated as a purely technical space for flows, machinery, or storage; hence, no specific human-oriented architectural design was considered [144].

Among the aforementioned three aspects, underground environments, psychological issues, and disaster prevention inside underground facilities have been extensively investigated in recent years.

\subsubsection{Underground quality}

The importance of underground physical space quality and the relevant psychological and health issues have long been noticed and discussed for more than three decades. These issues can be grouped into three categories, namely 1) environmental stressors such as thermal comfort, air quality, noise, lighting, and windowless environment $[145], 2)$ socio-psychological issues such as negative culture-based attitudes (related to burial and evil) and lack of perceived control (due to difficult way-finding and darkness) [146,147], 3) health issues such as circadian disruption, vitamin D deficiency, claustrophobic reactions, and sick building syndrome [148]. However, most of the early studies are descriptive and methodologically out-ofdate.

To fill this gap, several research projects have been undertaken for a deeper understanding of the humanistic design mechanisms of quality underground space. The employment of advanced neurocognitive methods and concepts is helpful for qualitative analysis.

Some measures and interventions for architectural design can be concluded from existing research. Climateadaptive ventilation strategies are suggested to create thermal comfort, as humidity is deemed a key factor 
affecting thermal behavior [149]. Sufficient and effective ventilation enhanced by particle filtration and air disinfection and avoiding air recirculation is also good for the air quality inside the UUI [150,151], which is particularly significant for the densely packed metro facilities to contain the human-to-human airborne transmission of the novel corona virus during the COVID-19 pandemic. The subjective loudness and acoustic comfort are related to the forms and geometries of underground shopping arcades (higher in "street type" than in "square type") and the humidity, air temperature, and luminance within the physical space [152]. The increase of sunlight use via the introduction of light pipes or sunken plaza is commonly suggested to create a better visual environment and improve visual and related health status [90]. Kim et al. [153], found that artificial windows are associated with increased response time while indoor plants in an underground environment can increase positive perceptions $[149,153]$. By reviewing the good design practices of metro stations, Hoeven and Juchnevic summarized the design principles as a well-designed entrance canopy, open station box, underground morphology and textures, architectural light, inter-visibility, art (such as colors and materials), spatial proportion, and proximity to other facilities [154]. The proportion of underground space is also mentioned as an important factor, e.g., for pedestrian tunnels, 5-6 $\mathrm{m}$ seems to be comfortable with an approximately 10 -fold length [155]. Meanwhile, to address the socio-psychological issues, measures such as the use of low-slope passageways that connect the underground space to the ground level [156], entering underground spaces through aboveground buildings, and a good orientation sign system [157] are suggested. However, the most effective measure to overcome psychological issues is to involve other humans, because as humans, we generally feel more comfortable around other people [155]. Therefore, the creation of an actively socializing underground space, including restaurants, supermarkets, shopping malls, indoor parks, or communal gyms, is strongly recommended [156].

\subsubsection{Disaster reduction and mitigation}

The most common disasters that might occur in underground physical spaces are floods and fire/blasts. Flood disasters (i.e., inundation events) have dramatically affected underpass interchanges and underground spaces [158] in megacities such as Seoul (1998), Taipei, China (2001), New York (2012), and Guangzhou (2016) [159] over the years. Such disasters are now occurring more frequently because of the global climate change and the rapid development of UUI facilities, notably metro systems in megacities. Therefore, inundation risk assessment for future UUI planning and existing UUI facilities is a prerequisite for disaster prevention as well as for the determination of priority areas for disaster reduction and mitigation. According to Lyu et al. [160-163], indicators related to risk assessment can be categorized into hazard (e.g., rainfall and land subsidence), exposure (e.g., elevation, slope, exit/entrance, and proximity to rivers), and vulnerability (e.g., population, GDP, land use, and construction status of metro and road facilities) ones. The general methods of inundation risk assessment resemble those employed for the suitability evaluation of UUS use, that is, AHP or fuzzy AHP [164-166] (e.g., interval AHP, triangular fuzzy number-based AHP, and AHP with fuzzy clustering analysis) incorporated into a GIS platform for spatial calculation and visualization, with fuzzy AHP methods yielding wider and higher risks.

Compared with floods, fires generate more internal challenges to UUI safety. Hot smoke incurred by fire in UUI is hazardous to human lives, while high temperatures induce property changes in the surrounding soil or rocks [167] and cause structural damage [168-172], thereby posing great threats to UUI safety. To alleviate these threats, numerous studies have been conducted to find plausible solutions. For instance, numerical simulations and experimental studies have found that the quantity and distribution of point openings directly affect the efficiency of smoke extraction $[173,174]$. New construction materials such as bio-inspired composites [175] and hybrid fibers [176] have been proven effective for improving the structural performance and spalling resistance of UUI structures.

From the perspective of architectural design, underground physical space differentiates from surface buildings in terms of lighting, ventilation, limited orientation, overlap of evacuation routes [177] and smoke [178] or flood paths, and ascending exit routes [179]. Therefore, holistic architectural regulations and standards are required to ensure proper safety design [180] and efficient evacuation, as parameterized by exit route (path) width, travel distance, relative location of exit doors [179], and the arrangement of ventilation shafts [181]. The effective measures used to counter external flood disasters include waterproofing facilities (e.g., counter-pressure doors, hinged double doors, shutters, and bi-fold doors) at all tunnel openings (e.g., tunnel entrances, ventilation openings, underground station entrances) and floodwater drainage systems [182].

\subsection{Construction technology}

Construction technologies play an important role in achieving sustainable UUS development. For instance, the conventional cut-and-cover approach is more likely than a bored tunnel to create barriers to future use for crossing UUIs and affect other UUS assets such as groundwater, space continuum, and underground organisms owing to the affiliated retaining structures such as diaphragm walls [28]. As the surface and shallow UUS 
become more congested, conventional construction technologies fail to meet the current needs and demands of urban development and SDGs delivery. Therefore, new concepts and technologies, predominantly from the following three aspects, are emerging in literature.

\subsubsection{Lower disturbance to space continuum}

To maintain the properties of the original space continuum to the extent possible, one requires micro-disturbed construction technology and control systems. Examples of micro-disturbed construction technologies include shield tunnels with a new cryogenic sealing process for launch and reception [183] and pneumatic caissons with remote-control technology [184]. According to Zhu et al. [185], the system includes three parts, namely survey, prediction, and decision before the construction, monitoring, and feedback control during construction, and longterm prediction and control after the construction.

\subsubsection{Underground extension of existing structures}

As mentioned above, UUI has a low capability for future expansion but is indeed a necessity in most cities because of the unexpectedly high urbanization rate. This also applies to surface buildings that require extra space to accommodate more services. Therefore, novel construction technologies are required to resolve these issues. For instance, two underground floors were newly added below the Tokyo Station during the preservation and restoration process [186], and a newly developed non-cut-and-cover enlargement method was proven to be feasible for expanding the cross-sectional dimension of a tunnel [187].

\subsubsection{Expansion of urban capacity}

The trend of UUI development is going deeper and larger. However, challenges are also emerging, as exemplified by geological uncertainties, prospecting and monitoring difficulties, design theory and methods, and excavation or drilling equipment [188]. Such deeper and larger UUI projects require better collaboration between various construction sections as well as a better grasp of the overall construction process and the real-time relationship between UUI structures and the surrounding environment of both the surface and subsurface.

\section{Framework for collaborative approach toward SDGs}

As can be seen from the previous two sections, the four dimensions, that is, modern land administration, integrated planning, architectural design, and construction technol- ogy, are all critical and inevitable when a city refers to UUS toward SDGs. Therefore, collaboration, coordination, and communication among the relevant sectors (which is herein called a collaborative approach) of the four dimensions are significant to ensure the value of UUS development [189].

The literature review in Section 4 reveals that data, notably those with spatial (locational or geographic) information, i.e., spatial data, are the underpinning prerequisite to address the key issues in the four critical dimensions. The current practices in urban management in each dimension demonstrate that SDI, which constitutes a set of relationships and partnerships delivering spatial data, services, and information for applications, is the key to establishing a collaborative approach among various urban sectors. The significance of SDI in enabling SDGs has been comprehensively addressed in the work of Rajabifard [190]. Explicitly, Rajabifard et al. [191] suggested adopting an Urban Analytics Data Infrastructure as an SDI for measuring and monitoring the national and local progress of SDGs. Therefore, this study suggests that an SDI-based collaborative approach is essential for UUS development toward SDGs. Based on the current exemplary experiences in related domains and the specific requirements of UUS development, this study proposes a framework for the SDI-based collaborative approach. As conceptualized in Fig. 2, the framework should be able to achieve at least the following three purposes to meet the requirements of the four critical dimensions.

\subsection{Data requirements for UUS}

As listed in Table 5 and analyzed in Section 4.1, the data requirements for underground $3 \mathrm{D}$ cadasters include $3 \mathrm{D}$ legal data and 3D physical data, which are also significant for UUS development toward SDGs. Spatial data can be used to represent underground legal and physical data, thus underpinning the collaborative approach among the four critical dimensions. In general, the existing spatial data concerning UUS development come from multiple sources with different formats and standards. The processing, sharing, and coordination of these data are technically challenging and time-consuming, which can be interpreted as inadequate interoperability. Moreover, the existing spatial data in most cases are privately kept by a given sector and are not accessible to other sectors and the general public, largely because of restrictive and competing policies. This is also a major source of engineering miscommunication, inefficiency, and accidents [192]. To address such issues, a shared SDI with the agreed standards and consistent policies of UUS spatial data are required.

The data supporting collaboration include at least the stratum data, geological data, cadastral data, structural data, architectural data, and socio-economic data. Over the 


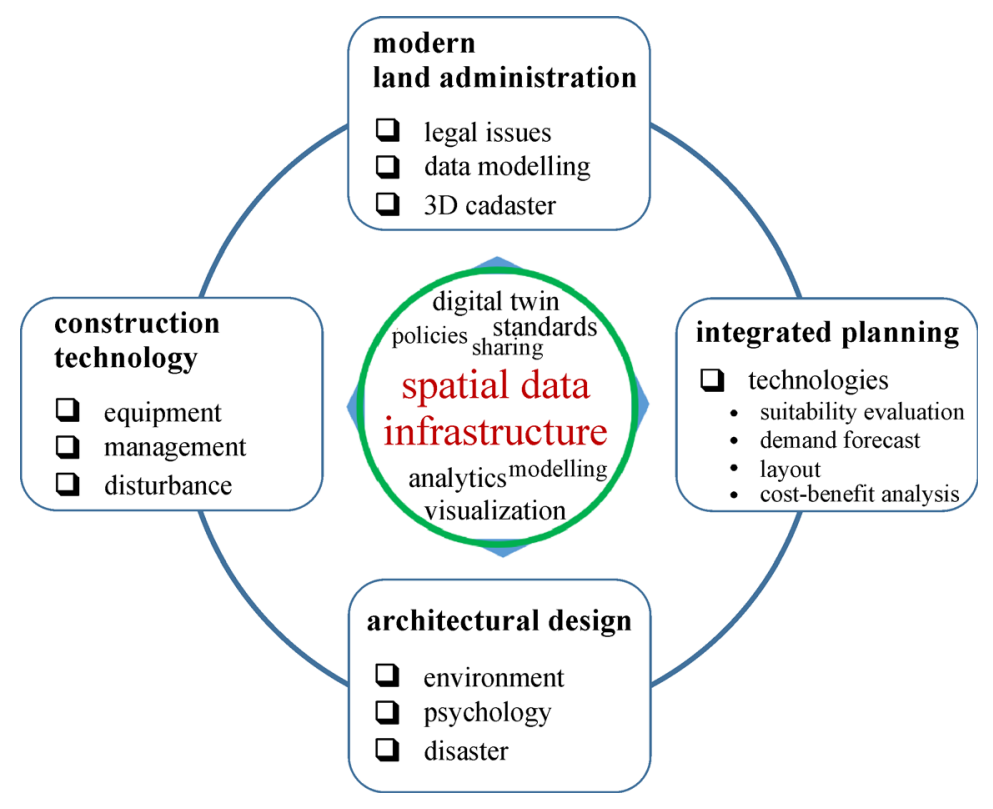

Fig. 2 SDI-based framework for the collaborative approach to UUS development.

last few decades, a number of initiatives (such as the Cost SubUrban) have emerged to improve the availability and utilization of subsurface data [189]. In addition, spatial metadata are also of key importance for the identification of, assessment of, and access to the data set via SDIs [193].

\subsection{Modeling and visualization}

As the underground world is invisible in most cases, the modeling and visualization of UUS-related data can facilitate the understanding of the underground status/ future and public engagement in the planning and design process, which sets up bridges between data providers and customers from the sectors of the four critical dimensions. The visualization of UUS should be in a $3 \mathrm{D}$ format so that it can (a) present the distribution of UUS assets, (b) tangle the disputes of UUS legal issues, (c) showcase the planning and architectural design results to the decision makers and the general public, and (d) manage the construction process of UUS projects. In addition, with the aid of advanced technologies, such as virtual reality, 4D visualization (time dimension added), and augmented reality, stakeholders can have a better understanding of the planning and architectural design in the virtual underground environment, which will aid the optimization of planning and design outcomes.

The ideal solution for UUS modeling and visualization is a digital twin platform. The incorporation of UUS into a spatially enabled digital twin is an intelligent method for real-time visualization, query, and analysis of physical and legal entities [194] in the complex but invisible underground world

\subsection{Analytics}

The analytics of UUS SDIs can be a decision support system in the following aspects: (a) it shows the immediate and long-term influences of UUI implementation on other UUS assets; (b) it helps to assess the suitability of UUS use in a 3D space; (c) it assists in forecasting the demand of UUS development; (d) it uses methods such as space syntax to assist UUS layout; (e) it demonstrates the contributions or losses derived from UUS use to SDGs in an understandable language (such as cost-benefit analysis); (f) it simulates fire or flood disasters; (g) it models the construction processes of UUS projects.

However, it should be noted that these aspects are not easy tasks, and many technical issues remain to be addressed to establish such a shared and intelligent SDI platform.

As such, the establishment of the collaborative approach involves such massive workloads that the institutional arrangements in most jurisdictions cannot keep pace with the multi-faceted challenges on legislation, data acquisition and registration, planning and design approval, disaster management, construction, etc. Therefore, a concerted and dedicated effort from an institution or department that is tailored for the UUS governor is required, particularly at the early stage.

\section{Conclusions}

Herein, we presented a comprehensive review of the relationship between UUS and urban sustainability from 
the perspective of the UN SDGs. This work covers a wide range of disciplinary areas to which extensive research efforts have been devoted, especially in the recent decade, and helps readers to form a holistic view of the concepts and major challenges of UUS research in various disciplines. The major objective is to raise the stakeholders' awareness of the role of UUS in achieving SDGs and promote the reasonable use of UUS to facilitate urban sustainability.

This review demonstrates that UUS use can help to realize 11 out of 17 SDGs, namely SDG 3 (good health and well-being), SDG 6 (clean water and sanitation), SDG 7 (affordable and clean energy), SDG 8 (decent work and economic growth), SDG 9 (industry, innovation, and infrastructure), SDG 11 (sustainable cities and communities), SDG 12 (responsible consumption and production), SDG 13 (climate action), SDG 15 (life on land), SDG 16 (peace, justice, and strong institutions), and SDG 17 (partnerships). However, the contribution of UUS to SDGs can be both positive and negative. Therefore, the overall targets of UUS use toward SDGs should be the maximization of benefits and the minimization of potential damages, including damage to UUS assets and urban functioning, particularly in terms of security and safety, health and well-being, upgrading capacity, and public space vitality. To this end, a collaborative approach is required.

The collaborative approach incorporates the four critical disciplinary dimensions, namely modern land administration, integrated planning, architectural design, and construction technology, each of which is a challenging domain with distinct research issues and specific requirements in terms of sustainable UUS use. A modern land administration system for UUS requires the removal of legal barriers and the establishment of a 3D cadaster. Integrated UUS planning considers at least suitability assessment, demand forecast, layout method, and costbenefit analysis at various planning levels. Specific design measures should be taken to improve underground architectural quality and reduce and mitigate underground internal fire or flood disasters. Advanced construction technologies and management are also required to address the challenges of increasingly complicated underground environments. These issues and requirements can be addressed to a great extent by the employment of SDI. The SDI-based collaborative approach should be established on a shared and intelligent platform equipped with various spatial data and capable of 3D modeling, visualization, and analytics.

In the future, more efforts should be made to quantify the contributions of UUS to SDGs so that clearer targets can be set up for UUS use. Meanwhile, methodological and technical challenges need to be addressed not only in the four critical dimensions but also in the establishment of the SDI platform.
Acknowledgements This work was supported by the National Key Technology R\&D Program (No. 2012BAJ01B04), the National Natural Science Foundation of China (Grant No. 42071251), and the China Scholarship Council (File No. 201806260167). The authors gratefully appreciate the polishing and editing efforts of editorial office and constructive comments of the two anonymous reviewers.

\section{References}

1. Chinese Academy of Engineering. Engineering Fronts 2018. Beijing: Higher Education Press, 2018

2. Underground Space Sub-Society of CSRME, WiSUSP. Blue Book of Urban Underground Space Development in China 2019. Beijing: Chinese Society for Rock Mechanics \& Engineering, 2019 (in Chinese)

3. Kishii T. Utilization of underground space in Japan. Tunnelling and Underground Space Technology, 2016, 55: 320-323

4. Doyle M R. From hydro/geology to the streetscape: Evaluating urban underground resource potential. Tunnelling and Underground Space Technology, 2016, 55: 83-95

5. Bobylev N, Jefferson I. Integration of urban physical infrastructure into land use governance. In: 2014 World Bank Conference on Land and Poverty. Washington, D.C.: The World Bank, 2014

6. Attarian K, Safar Ali Najar B. Vernacular and historic underground urban facilities and sustainability of cities case study: Infrastructures of Dezful. Journal of Cultural Heritage Management and Sustainable Development, 2019, 9(1): 2-23

7. Halisçelik E, Soytas M A. Sustainable development from millennium 2015 to sustainable development goals 2030. Sustainable Development, 2019, 27(4): 545-572

8. Griggs D, Stafford-Smith M, Gaffney O, Rockström J, Öhman M C, Shyamsundar P, Steffen W, Glaser G, Kanie N, Noble I. Sustainable development goals for people and planet. Nature, 2013, 495(7441): 305-307

9. Scott G, Rajabifard A. Sustainable development and geospatial information: A strategic framework for integrating a global policy agenda into national geospatial capabilities. Geo-Spatial Information Science, 2017, 20(2): 59-76

10. United Nations. Report of the Secretary-General on SDG Progress 2019 (special edition). 2019

11. Fu B, Wang S, Zhang J, Hou Z, Li J. Unravelling the complexity in achieving the 17 sustainable-development goals. National Science Review, 2019, 6(3): 386-388

12. Alcamo J. Water quality and its interlinkages with the Sustainable Development Goals. Current Opinion in Environmental Sustainability, 2019, 36: 126-140

13. Bouma J. Soil science contributions towards sustainable development goals and their implementation: Linking soil functions with ecosystem services. Journal of Plant Nutrition and Soil Science, 2014, 177(2): 111-120

14. Terlau W, Hirsch D, Blanke M. Smallholder farmers as a backbone for the implementation of the Sustainable Development Goals. Sustainable Development, 2019, 27(3): 523-529

15. Fuso Nerini F, Tomei J, To L S, Bisaga I, Parikh P, Black M, Borrion A, Spataru C, Castán Broto V, Anandarajah G, Milligan B, 
Mulugetta Y. Mapping synergies and trade-offs between energy and the Sustainable Development Goals. Nature Energy, 2018, 3(1): 10-15

16. Martin D A. Linking fire and the United Nations Sustainable Development Goals. Science of the Total Environment, 2019, 662: 547-558

17. Wood S L, Jones S K, Johnson J A, Brauman K A, Chaplin-Kramer R, Fremier A, Girvetz E, Gordon L J, Kappel C V, Mandle L, Mulligan M, O'Farrell P, Smith W K, Willemen L, Zhang W, DeClerck F A. Distilling the role of ecosystem services in the Sustainable Development Goals. Ecosystem Services, 2018, 29: 70-82

18. de Oliveira Neto G C, Ferreira Correia J M, Silva P C, de Oliveira Sanches A G, Lucato W C. Cleaner Production in the textile industry and its relationship to sustainable development goals. Journal of Cleaner Production, 2019, 228: 1514-1525

19. Alawneh R, Ghazali F, Ali H, Sadullah A F. A Novel framework for integrating United Nations Sustainable Development Goals into sustainable non-residential building assessment and management in Jordan. Sustainable Cities and Society, 2019, 49: 101612

20. Sabri S, Rajabifard A. Spatial enablement to facilitate the new urban agenda commitments for sustainable development. In: Sustainable Development Goals Connectivity Dilemma (Open Access): Land and Geospatial Information for Urban and Rural Resilience. Boca Raton: CRC Press, 2020, 199-211

21. Rönkä K, Ritola J, Rauhala K. Underground space in land-use planning. Tunnelling and Underground Space Technology, 1998, 13(1): 39-49

22. Bobylev N. Underground space as an urban indicator: Measuring use of subsurface. Tunnelling and Underground Space Technology, 2016, 55: 40-51

23. Bobylev N. Mainstreaming sustainable development into a city's master plan: A case of urban underground space use. Land Use Policy, 2009, 26(4): 1128-1137

24. Parriaux A, Blunier P, Maire P, Tacher L. The DEEP CITY project: A global concept for a sustainable urban underground management. In: Proceedings of 11th ACUUS International Conference. Athens: the 11th ACUUS Conference Organizing Committee, 2007, 255-260

25. Li H Q, Parriaux A, Thalmann P, Li X Z. An integrated planning concept for the emerging underground urbanism: Deep City Method Part 1 concept, process and application. Tunnelling and Underground Space Technology, 2013, 38: 559-568

26. Li H, Li X, Parriaux A, Thalmann P. An integrated planning concept for the emerging underground urbanism: Deep City Method Part 2 case study for resource supply and project valuation. Tunnelling and Underground Space Technology, 2013, 38: 569580

27. Li X, Li C, Parriaux A, Wu W, Li H, Sun L, Liu C. Multiple resources and their sustainable development in Urban Underground Space. Tunnelling and Underground Space Technology, 2016, 55: 59-66

28. Sterling R, Admiraal H, Bobylev N, Parker H, Godard J P, Vähäaho I, Rogers C D F, Shi X D, Hanamura T. Sustainability issues for underground space in urban areas. Proceedings of the Institution of Civil Engineers, Urban Design and Planning, 2012,
165(4): 241-254

29. Qiao Y K, Peng F L, Sabri S, Rajabifard A. Socio-environmental costs of underground space use for urban sustainability. Sustainable Cities and Society, 2019, 51: 101757

30. Qiao Y K, Peng F L, Wang Y. Monetary valuation of urban underground space: A critical issue for the decision-making of urban underground space development. Land Use Policy, 2017, 69: $12-24$

31. Qiao Y K, Peng F L, Wang Y. Valuing external benefits of underground rail transit in monetary terms: A practical method applied to Changzhou City. Tunnelling and Underground Space Technology, 2019, 83: 91-98

32. van Ree C C D F, van Beukering P J H. Geosystem services: A concept in support of sustainable development of the subsurface. Ecosystem Services, 2016, 20: 30-36

33. van Ree C C D F, van Beukering P J H, Boekestijn J. Geosystem services: A hidden link in ecosystem management. Ecosystem Services, 2017, 26: 58-69

34. Schrodt F, Bailey J J, Kissling W D, Rijsdijk K F, Seijmonsbergen A C, Van Ree D, Hjort J, Lawley R S, Williams C N, Anderson M G, Beier P, van Beukering P, Boyd D S, Brilha J, Carcavilla L, Dahlin K M, Gill J C, Gordon J E, Gray M, Grundy M, Hunter M L, Lawler J J, Monge-Ganuzas M, Royse K R, Stewart I, Record S, Turner W, Zarnetske P L, Field R. Opinion: To advance sustainable stewardship, we must document not only biodiversity but geodiversity. Proceedings of the National Academy of Sciences of the United States of America, 2019, 116(33): 16155-16158

35. Zargarian R, Hunt D V, Braithwaite P, Bobylev N, Rogers C D. A new sustainability framework for urban underground space. Proceedings of the Institution of Civil Engineers-Engineering Sustainability, 2018, 171(5): 238-253

36. Hunt D V, Jefferson I, Rogers C D. Assessing the sustainability of underground space usage- $\mathrm{A}$ toolkit for testing possible urban futures. Journal of Mountain Science, 2011, 8(2): 211-222

37. Chen Y, Guo D, Chen Z, Fan Y, Li X. Using a multi-objective programming model to validate feasibility of an underground freight transportation system for the Yangshan port in Shanghai. Tunnelling and Underground Space Technology, 2018, 81: 463471

38. Yeung J S, Wong Y D. The effect of road tunnel environment on car following behaviour. Accident, Analysis and Prevention, 2014, 70: 100-109

39. Ma C X, Peng F L. Some aspects on the planning of complex underground roads for motor vehicles in Chinese cities. Tunnelling and Underground Space Technology, 2018, 82: 592-612

40. Chen Y, Whalley A. Green infrastructure: The effects of urban rail transit on air quality. American Economic Journal. Economic Policy, 2012, 4(1): 58-97

41. Jovičić V, Volk B, Logar J. Conditions for the sustainable development of underground transport in the Ljubljana Basin. Sustainability, 2018, 10(9): 2971

42. Qihu Q. Present state, problems and development trends of urban underground space in China. Tunnelling and Underground Space Technology, 2016, 55: 280-289

43. Li H Q, Fan Y Q, Yu M J. Deep Shanghai project-A strategy of infrastructure integration for megacities. Tunnelling and Under- 
ground Space Technology, 2018, 81: 547-567

44. Wallace M I, Ng K C. Development and application of underground space use in Hong Kong. Tunnelling and Underground Space Technology, 2016, 55: 257-279

45. Schmoll O, Howard G, Chilton J, Chorus I. Protecting Groundwater for Health: Managing the Quality of Drinking-Water Sources. Geneva: World Health Organization, 2006

46. Beardsmore G, Dumitrescu I, Harrison B, Sandiford M R. Victorian Geothermal Assessment Report. 2016

47. National Development and Reform Commission. Development Review of Urban Rail Transit Industry in the 13th Five-Year Period. 2017 (available at the website of National Development and Reform Commission) (in Chinese)

48. Chen Z L, Chen J Y, Liu H, Zhang Z F. Present status and development trends of underground space in Chinese cities: Evaluation and analysis. Tunnelling and Underground Space Technology, 2018, 71: 253-270

49. Liu M B, Liao S M. A case study on the underground rapid transport system (URTS) for the international airport hubs: Planning, application and lessons learnt. Tunnelling and Underground Space Technology, 2018, 80: 114-122

50. Valdenebro J V, Gimena F N. Urban utility tunnels as a long-term solution for the sustainable revitalization of historic centres: The case study of Pamplona-Spain. Tunnelling and Underground Space Technology, 2018, 81: 228-236

51. Zhou Y, Zhao J. Assessment and planning of underground space use in Singapore. Tunnelling and Underground Space Technology, 2016, 55: 249-256

52. Tkachenko N, Bricker S, Jarvis S A. To dig or not to dig? Place and perception in subsurface housing. Proceedings of the Institution of Civil Engineers-Engineering Sustainability, 2018, 171(4): 211220

53. Kim A M. The extreme primacy of location: Beijing's underground rental housing market. Cities (London, England), 2016, 52: 148158

54. Qiao Y K, Peng F L, Wu X L, Ding S F. Underground space planning in urban built-up areas: A case study of Qingdao, China. In: Proceedings of 16th ACUUS International Conference. Hong Kong, China: 16th ACUUS Conference Organizing Committee, 2018, 255-265

55. Zhao L, Li H, Li M, Sun Y, Hu Q, Mao S, Li J, Xue J. Location selection of intra-city distribution hubs in the metro-integrated logistics system. Tunnelling and Underground Space Technology, 2018, 80: 246-256

56. Glazer A. Underground cemetery construction in Jerusalem. In: Proceedings of 16th ACUUS International Conference. Hong Kong, China: 16th ACUUS Conference Organizing Committee, 2018, 123-130

57. Qiao Y K, Peng F L. Master planning for underground space in Luoyang: A case of a representative historic city in China. Procedia Engineering, 2016, 165: 119-125

58. Sterling R, Nelson P. City resiliency and underground space use. In: Proceedings of 13th ACUUS International Conference Advances in Underground Space Development. Singapore: 4th UPPD Conference Organizing Committee, 2013, 43-55

59. Admiraal H, Cornaro A. Future cities, resilient cities - The role of underground space in achieving urban resilience. Underground Space, 2019 (in press)

60. Vähäaho I. An introduction to the development for urban underground space in Helsinki. Tunnelling and Underground Space Technology, 2016, 55: 324-328

61. Hidalgo D, Martin-Marroquin J M, Corona F, Juaristi J L. Sustainable vacuum waste collection systems in areas of difficult access. Tunnelling and Underground Space Technology, 2018, 81: 221-227

62. Magnusson S, Lundberg K, Svedberg B, Knutsson S. Sustainable management of excavated soil and rock in urban areas-A literature review. Journal of Cleaner Production, 2015, 93: 18-25

63. Katsumi T. Soil excavation and reclamation in civil engineering: Environmental aspects. Soil science and plant nutrition, 2015, 61(sup1): 22-29

64. Broch E. Planning and utilisation of rock caverns and tunnels in Norway. Tunnelling and Underground Space Technology, 2016, 55: $329-338$

65. Takasaki H, Chikahisa H, Yuasa Y. Planning and mapping of subsurface space in Japan. Tunnelling and Underground Space Technology, 2000, 15(3): 287-301

66. El-Geneidy A, Kastelberger L, Abdelhamid H. Montréal's Roots: Exploring the growth of Montréal's Indoor City. Journal of Transport and Land Use, 2011, 4(2): 33-46

67. Shi W, Jia B, Ponte A, Wee H K. Multi-layer system of urban open space-Study in Montreal. New Arch-International Journal of Contemporary Architecture, 2017, 4(3): 1-8

68. Tajima K. New estimates of the demand for urban green space: Implications for valuing the environmental benefits of Boston's big dig project. Journal of Urban Affairs, 2003, 25(5): 641-655

69. Qiao Y K, Peng F L, Sabri S, Rajabifard A. Low carbon effects of urban underground space. Sustainable Cities and Society, 2019, 45: 451-459

70. Yang X, Chen Z, Cai H, Ma L. A framework for assessment of the influence of China's urban underground space developments on the urban microclimate. Sustainability, 2014, 6(12): 8536-8566

71. Lacey E A, Patton J L. Life Underground: The Biology of Subterranean Rodents. Chicago: University of Chicago Press, 2000

72. Wu H N, Shen S L, Chen R P, Zhou A N. Three-dimensional numerical modelling on localised leakage in segmental lining of shield tunnels. Computers and Geotechnics, 2020, 122: 103549

73. Vieira A, Alberdi-Pagola M, Christodoulides P, Javed S, Loveridge F, Nguyen F, Cecinato F, Maranha J, Florides G, Prodan I, Van Lysebetten G, Ramalho E, Salciarini D, Georgiev A, RosinPaumier S, Popov R, Lenart S, Erbs Poulsen S, Radioti G. Characterisation of ground thermal and thermo-mechanical behaviour for shallow geothermal energy applications. Energies, 2017, 10(12): 2044

74. Bidarmaghz A, Narsilio G A. Heat exchange mechanisms in energy tunnel systems. Geomechanics for Energy and the Environment, 2018, 16: 83-95

75. Bayer P, Attard G, Blum P, Menberg K. The geothermal potential of cities. Renewable \& Sustainable Energy Reviews, 2019, 106: $17-30$

76. Wu Y X, Shen S L, Yuan D J. Characteristics of dewatering induced drawdown curve under blocking effect of retaining wall in 
aquifer. Journal of Hydrology (Amsterdam), 2016, 539: 554-566

77. Attard G, Winiarski T, Rossier Y, Eisenlohr L. Impact of underground structures on the flow of urban groundwater. Hydrogeology Journal, 2016, 24(1): 5-19

78. Wu Y X, Lyu H M, Shen S L, Zhou A N. A three-dimensional fluid-solid coupled numerical modeling of the barrier leakage below the excavation surface due to dewatering. Hydrogeology Journal, 2020, 28(4): 1449-1463

79. Wu Y X, Shen S L, Lyu H M, Zhou A N. Analyses of leakage effect of waterproof curtain during excavation dewatering. Journal of Hydrology (Amsterdam), 2020, 583: 124582

80. Kang $\mathrm{P}, \mathrm{Xu} \mathrm{S}$. The impact of an underground cut-off wall on nutrient dynamics in groundwater in the lower Wang River watershed, China. Isotopes in Environmental and Health Studies, 2017, 53(1): 36-53

81. Chae G T, Yun S T, Choi B Y, Yu S Y, Jo H Y, Mayer B, Kim Y J, Lee J Y. Hydrochemistry of urban groundwater, Seoul, Korea: The impact of subway tunnels on groundwater quality. Journal of Contaminant Hydrology, 2008, 101(1-4): 42-52

82. Sun J. Cost-benefit analysis of building waste recycling in China. Construction Science and Technology, 2016, 13: 121-123 (in Chinese)

83. Di W, Chang H. The heritage impact assessment study of Xi'an metro Line 5. Xi'an: Xi'an University of Architecture and Technology, 2013 (in Chinese)

84. Ge J, Wang S, Sun X, Ma B, Yang W. Study on metro trafficinduced vibration and the security of relics. Sciences of Conservation and Archaeology, 2015, 27(1): 7-14 (in Chinese)

85. Mulec J. Human impact on underground cultural and natural heritage sites, biological parameters of monitoring and remediation actions for insensitive surfaces: Case of Slovenian show caves. Journal for Nature Conservation, 2014, 22(2): 132-141

86. Babel M S, Gupta A D, Domingo N D. Land subsidence: A consequence of groundwater over-exploitation in Bangkok, Thailand. International Review for Environmental Strategies, 2006, 6(2): 307-327

87. Wu Y X, Lyu H M, Han J, Shen S L. Dewatering-induced building settlement around a deep excavation in soft deposit in Tianjin, China. Journal of Geotechnical and Geoenvironmental Engineering, 2019, 145(5): 05019003

88. Tan Y, Wang D. Characteristics of a large-scale deep foundation pit excavated by the central-island technique in Shanghai soft clay. I: Bottom-up construction of the central cylindrical shaft. Journal of Geotechnical and Geoenvironmental Engineering, 2013, 139(11): $1875-1893$

89. Cui J, Nelson J D. Underground transport: An overview. Tunnelling and Underground Space Technology, 2019, 87: 122126

90. Durmisevic S. The future of the underground space. Cities (London, England), 1999, 16(4): 233-245

91. Shan M, Hwang B G, Wong K S N. A preliminary investigation of underground residential buildings: Advantages, disadvantages, and critical risks. Tunnelling and Underground Space Technology, 2017, 70: 19-29

92. Broere W. Urban underground space: Solving the problems of today's cities. Tunnelling and Underground Space Technology,
2016, 55: 245-248

93. Peng F L, Qiao Y K, Zhao J W, Liu K, Li J C. Planning and implementation of underground space in Chinese central business district (CBD): A case of Shanghai Hongqiao CBD. Tunnelling and Underground Space Technology, 2020, 95: 103176

94. Zacharias J, He J. Hong Kong's urban planning experiment in enhancing pedestrian movement from underground space to the surface. Tunnelling and Underground Space Technology, 2018, 82: $1-8$

95. Qiao Y K, Peng F L, Liu Y, Zhang Y C. Balancing conservation and development in historic cities by underground solutions. In: Proceedings of 4th UPPD International Conference. Singapore, 2018: 10-15

96. Barker M. Legal and administrative issues in underground space use: A preliminary survey of ITA member nations. Tunnelling and Underground Space Technology, 1991, 6(2): 191-209

97. Rajabifard A, Atazadeh B, Kalantari M. BIM and urban land administration. Boca Raton: CRC Press, 2019

98. Sandberg H. Three-dimensional partition and registration of subsurface land space. Israel Law Review, 2003, 37(1): 119-167

99. Guo R, Li L, Ying S, Luo P, He B, Jiang R. Developing a 3D cadastre for the administration of urban land use: A case study of Shenzhen, China. Computers, Environment and Urban Systems, 2013, 40: 46-55

100. Zaini F, Hussin K, Raid M M. Legal considerations for urban underground space development in Malaysia. Underground Space, 2017, 2(4): 234-245

101. Rajabifard A, Atazadeh B, Kalantari M. A critical evaluation of 3D spatial information models for managing legal arrangements of multi-owned developments in Victoria, Australia. International Journal of Geographical Information Science, 2018, 32(10): 20982122

102. Pasqual J, Riera P. Underground land values. Land Use Policy, 2005, 22(4): 322-330

103. Fu J, Yang J. A study on value and price of urban underground space resources. Thesis for the Master's Degree. Beijing: Tsinghua University, 2009 (in Chinese)

104. Li S, Yang M, Li C. Research on base price evaluation method and application of urban underground: A case study of Guangzhou Higher Education Mega Center. Thesis for the Master's Degree. Guangzhou: Guangzhou University, 2012 (in Chinese)

105. Tang Y. Study on land price appraisal of urban underground space: A case study of Cixi. Thesis for the Master's Degree. Hangzhou: Zhejiang University, 2015 (in Chinese)

106. Zhao L. Analysis and discussion on land-use right price of urban underground space in China. Chinese Journal of Underground Space and Engineering, 2015, 11(2): 284-292 (in Chinese)

107. Liao M, Qu Z. Income method in underground space for the application of land price evaluation. Thesis for the Master's Degree. Shenyang: Liaoning University, 2015 (in Chinese)

108. Isikdag U, Horhammer M, Zlatanova S, Kathmann R, Van Oosterom P J. Utilizing 3D building and 3D cadastre geometries for better valuation of existing real estate. In: Proceedings FIG Working Week 2015 'From the wisdom of the ages to the challenges of modern world'. Sofia, Bulgaria: FIG Working Week 2015 Organizing Committee, 2015, 1-18 
109. Kim S, Heo J. Registration of 3D underground parcel in Korean cadastral system. Cities (London, England), 2019, 89: 105-119

110. Guo R, Li L, He B, Luo P, Zhao Z, Ying S, Jiang R. 3D Cadastre in China-A case study in Shenzhen City. In: Proceedings of the 2nd International Workshop on 3D Cadastres. Delft: Organizing Committee, 2011, 291-310

111. Ho S, Rajabifard A, Kalantari M. 'Invisible' constraints on 3D innovation in land administration: A case study on the city of Melbourne. Land Use Policy, 2015, 42: 412-425

112. Shojaei D, Olfat H, Quinones Faundez S I, Kalantari M, Rajabifard A, Briffa M. Geometrical data validation in 3D digital cadastre-A case study for Victoria, Australia. Land Use Policy, 2017, 68: 638648

113. Kalantari M, Yip K M, Atazadeh B, ISA D, Adimin M, Chan K, Aien A, Olfat H, Shojaei D, Anaraki M R. An LADM-based Approach for Developing and Implementing a National 3D Cadastre-A Case Study of Malaysia. In: Proceedings of the 7th International FIG Workshop on the Land Administration Domain Model. Zagreb: Organizing Committee, 2018, 47-66

114. Ho S, Rajabifard A. Towards 3D-enabled urban land administration: Strategic lessons from the BIM initiative in Singapore. Land Use Policy, 2016, 57: 1-10

115. Kim S, Heo J. Development of 3D underground cadastral data model in Korea: Based on land administration domain model. Land Use Policy, 2017, 60: 123-138

116. Atazadeh B, Kalantari M, Rajabifard A, Ho S, Champion T. Extending a BIM-based data model to support 3D digital management of complex ownership spaces. International Journal of Geographical Information Science, 2017, 31(3): 499-522

117. Atazadeh B, Kalantari M, Rajabifard A, Ho S. Modelling building ownership boundaries within BIM environment: A case study in Victoria, Australia. Computers, Environment and Urban Systems, 2017, 61: 24-38

118. ISO19152. Geographic Information-land Administration Domain Model (LADM). Geneva, Switzerland: International Organization for Standardization, 2012

119. von der Tann L, Sterling R, Zhou Y, Metje N. Systems approaches to urban underground space planning and management-A review. Underground Space, 2020, 5(2): 144-166

120. Admiraal H, Cornaro A. Why underground space should be included in urban planning policy-And how this will enhance an urban underground future. Tunnelling and Underground Space Technology, 2016, 55: 214-220

121. Zerhouny M, Fadil A, Hakdaoui M. Underground space utilization in the urban land-use planning of casablanca (Morocco). Land (Basel), 2018, 7(4): 143

122. Peng F, Qiao Y, Cheng G, Zhu H. Current situation and existing problems of and coping strategies for urban underground space planning in China. Earth Science Frontiers, 2019, 26(3): 57-68 (in Chinese)

123. Rönkä K, Ritola J, Rauhala K. Underground space in land-use planning. Tunnelling and Underground Space Technology, 1998, 13(1): 39-49

124. Vähäaho I. 0-land use: Underground resources and master plan in Helsinki. In: Advances in Underground Space Development. Singapore: Research Publishing, 2013, 29-42
125. Kaliampakos D, Benardos A, Mavrikos A. A review on the economics of underground space utilization. Tunnelling and Underground Space Technology, 2016, 55: 236-244

126. Doyle M, Thalmann P, Parriaux A. Underground potential for urban sustainability: Mapping resources and their interactions with the Deep City Method. Sustainability, 2016, 8(9): 830

127. Doyle M R. 'Resources to needs': A paradigm for addressing the potentiality of the urban volume. Urban Planning, 2017, 2(1): 6-18

128. Lu Z, Wu L, Zhuang X, Rabczuk T. Quantitative assessment of engineering geological suitability for multilayer Urban Underground Space. Tunnelling and Underground Space Technology, 2016, 59: 65-76

129. Peng J, Peng F L. A GIS-based evaluation method of underground space resources for urban spatial planning: Part 1 methodology. Tunnelling and Underground Space Technology, 2018, 74: 82-95

130. Peng J, Peng F L. A GIS-based evaluation method of underground space resources for urban spatial planning: Part 2 application. Tunnelling and Underground Space Technology, 2018, 77: 142165

131. Zhou D, Li X, Wang Q, Wang R, Wang T, Gu Q, Xin Y. GIS-based urban underground space resources evaluation toward threedimensional land planning: A case study in Nantong, China. Tunnelling and Underground Space Technology, 2019, 84: 1-10

132. Price S J, Terrington R L, Busby J, Bricker S, Berry T. 3D grounduse optimisation for sustainable urban development planning: A case-study from Earls Court, London, UK. Tunnelling and Underground Space Technology, 2018, 81: 144-164

133. Li X, Xu H, Li C, Sun L, Wang R. Study on the demand and driving factors of urban underground space use. Tunnelling and Underground Space Technology, 2016, 55: 52-58

134. Makana L O, Jefferson I, Hunt D V, Rogers C D. Assessment of the future resilience of sustainable urban sub-surface environments. Tunnelling and Underground Space Technology, 2016, 55 : 21-31

135. Xie H, Gao M, Zhang R, Xu H, Wang Y, Deng J. The subversive idea and its key technical prospect on underground ecological city and ecosystem. Chinese Journal of Rock Mechanics and Engineering, 2017, 36(6): 1301-1313 (in Chinese)

136. Peng J, Peng F L, Yabuki N, Fukuda T. Factors in the development of urban underground space surrounding metro stations: A case study of Osaka, Japan. Tunnelling and Underground Space Technology, 2019, 91: 103009

137. He L, Song Y, Dai S, Durbak K. Quantitative research on the capacity of urban underground space-The case of Shanghai, China. Tunnelling and Underground Space Technology, 2012, 32: $168-179$

138. ITA Working Group on Costs-Benefits of Underground Urban Transportation. Cost-benefit methods for underground urban public transportation systems. Tunnelling and Underground Space Technology, 1990, 5(1-2): 39-68

139. Lin J J, Lo C W. Valuing user external benefits and developing management strategies for metro system underground arcades. Tunnelling and Underground Space Technology, 2008, 23(2): 103110

140. Nishi J, Tanaka T, Seiki T, Ito H, Okuyama K. Estimation of the value of the internal and external environment in underground 
space use. Tunnelling and Underground Space Technology, 2000, 15(1): 79-89

141. Zhao J W, Peng F L, Wang T Q, Zhang X Y, Jiang B N. Advances in master planning of urban underground space (UUS) in China. Tunnelling and Underground Space Technology, 2016, 55: 290307

142. Qiao Y K, Peng F L. Lessons learnt from urban underground space use in Shanghai-From Lujiazui business district to Hongqiao central business district. Tunnelling and Underground Space Technology, 2016, 55: 308-319

143. Peng F L, Zhao J W, Liu K, Li J C. Underground Development Control in CBD Based on the Regulatory Plan: The Case of Phase I of Shanghai Hongqiao CBD. Urban Planning Forum, 2013, 1: 7884 (in Chinese)

144. Labbé M. Architecture of underground spaces: From isolated innovations to connected urbanism. Tunnelling and Underground Space Technology, 2016, 55: 153-175

145. Roberts A C, Christopoulos G I, Car J, Soh C K, Lu M. Psychobiological factors associated with underground spaces: What can the new era of cognitive neuroscience offer to their study? Tunnelling and Underground Space Technology, 2016, 55: 118134

146. Lee E H, Christopoulos G I, Lu M, Heo M Q, Soh C K. Social aspects of working in underground spaces. Tunnelling and Underground Space Technology, 2016, 55: 135-145

147. Lee E H, Luo C, Sam Y L, Roberts A C, Kwok K W, Car J, Soh C $\mathrm{K}$, Christopoulos G I. The underground workspaces questionnaire (UWSQ): Investigating public attitudes toward working in underground spaces. Building and Environment, 2019, 153: 28-34

148. Nang E E, Abuduxike G, Posadzki P, Divakar U, Visvalingam N, Nazeha N, Dunleavy G, Christopoulos G I, Soh C K, Jarbrink K, Soljak M, Car J. Review of the potential health effects of light and environmental exposures in underground workplaces. Tunnelling and Underground Space Technology, 2019, 84: 201-209

149. Tan Z, Roberts A C, Christopoulos G I, Kwok K W, Car J, Li X, Soh C K. Working in underground spaces: Architectural parameters, perceptions and thermal comfort measurements. Tunnelling and Underground Space Technology, 2018, 71: 428439

150. Okubo T, Osaki T, Nozaki E, Uemura A, Sakai K, Matushita M, Matsuo J, Nakamura S, Kamiya S, Yamaguchi H. Walker occupancy has an impact on changing airborne bacterial communities in an underground pedestrian space, as small-dust particles increased with raising both temperature and humidity. PLoS One, 2017, 12(9): e0184980

151. Morawska L, Tang J W, Bahnfleth W, Bluyssen P M, Boerstra A, Buonanno G, Cao J, Dancer S, Floto A, Franchimon F, Haworth C, Hogeling J, Isaxon C, Jimenez J L, Kurnitski J, Li Y, Loomans M, Marks G, Marr L C, Mazzarella L, Melikov A K, Miller S, Milton D K, Nazaroff W, Nielsen P V, Noakes C, Peccia J, Querol X, Sekhar C, Seppänen O, Tanabe S, Tellier R, Tham K W, Wargocki P, Wierzbicka A, Yao M. How can airborne transmission of COVID-19 indoors be minimised? Environment International, 2020, 142: 105832

152. Meng Q, Kang J, Jin H. Field study on the influence of spatial and environmental characteristics on the evaluation of subjective loudness and acoustic comfort in underground shopping streets. Applied Acoustics, 2013, 74(8): 1001-1009

153. Kim J, Cha S H, Koo C, Tang S K. The effects of indoor plants and artificial windows in an underground environment. Building and Environment, 2018, 138: 53-62

154. van der Hoeven F, Juchnevic K. The significance of the underground experience: Selection of reference design cases from the underground public transport stations and interchanges of the European Union. Tunnelling and Underground Space Technology, 2016, 55: 176-193

155. Ciepiela A. Underground Public Space. Cracow's Tunnels of Fear? Materials Science and Engineering, 2019, 471(9): 092017

156. Lee E H, Christopoulos G I, Kwok K W, Roberts A C, Soh C K. A psychosocial approach to understanding underground spaces. Frontiers in Psychology, 2017, 8: 452

157. Wang B Y, Shu Y. Study of directional indicator design in underground space. Journal of Tongji University, 2002, 30(1): 111-115

158. Shi Y, Zhai G, Zhou S, Lu Y, Chen W, Deng J. How can cities respond to flood disaster risks under multi-scenario simulation? A case study of Xiamen, China. International Journal of Environmental Research and Public Health, 2019, 16(4): 618

159. Wu J, Fang W, Hu Z, Hong B. Application of Bayesian approach to dynamic assessment of flood in urban underground spaces. Water (Basel), 2018, 10(9): 1112

160. Lyu H M, Sun W J, Shen S L, Arulrajah A. Flood risk assessment in metro systems of mega-cities using a GIS-based modeling approach. Science of the Total Environment, 2018, 626: 10121025

161. Lyu H M, Shen S L, Zhou A N, Zhou W H. Flood risk assessment of metro systems in a subsiding environment using the interval FAHP-FCA approach. Sustainable Cities and Society, 2019, 50: 101682

162. Lyu H M, Shen S L, Yang J, Yin Z Y. Inundation analysis of metro systems with the storm water management model incorporated into a geographical information system. Hydrology and Earth System Sciences, 2019, 23(10): 4293-4307

163. Lyu H M, Zhou W H, Shen S L, Zhou A N. Inundation risk assessment of metro system using AHP and TFN-AHP in Shenzhen. Sustainable Cities and Society, 2020, 56: 102103

164. Lyu H M, Sun W J, Shen S L, Zhou A. Risk assessment using a new consulting process in fuzzy AHP. Journal of Construction Engineering and Management, 2020, 146(3): 04019112

165. Lyu H M, Shen S L, Yang J, Zhou A. Risk assessment of earthquake-triggered geohazards surrounding Wenchuan, China. Natural Hazards Review, 2020, 21(3): 05020007

166. Lyu H M, Shen S L, Zhou A, Yang J. Risk assessment of mega-city infrastructures related to land subsidence using improved trapezoidal FAHP. Science of the Total Environment, 2020, 717: 135310

167. Chen Z, Zhu H, Yan Z, Zhao L, Shen Y, Misra A. Experimental study on physical properties of soft soil after high temperature exposure. Engineering Geology, 2016, 204: 14-22

168. Yan Z G, Zhang Y, Shen Y, Zhu H, Lu Y. A multilayer thermoelastic damage model for the bending deflection of the tunnel lining segment exposed to high temperatures. Tunnelling and Under- 
ground Space Technology, 2020, 95: 103142

169. Zhang Y, Ju J W, Chen Q, Yan Z, Zhu H, Jiang Z. Characterizing and analyzing the residual interfacial behavior of steel fibers embedded into cement-based matrices after exposure to high temperatures. Composites. Part B, Engineering, 2020, 191: 107933

170. Zhang Y, Ju J W, Zhu H, Guo Q, Yan Z. Micromechanics based multi-level model for predicting the coefficients of thermal expansion of hybrid fiber reinforced concrete. Construction \& Building Materials, 2018, 190: 948-963

171. Yan Z, Shen Y, Zhu H, Lu Y. Experimental Study of Tunnel Segmental joints Subjected to Elevated Temperature. Tunnelling and Underground Space Technology, 2016, 53: 46-60

172. Yan Z, Guo Q, Zhu H. Full-scale experiments on fire characteristics of road tunnel at high altitude. Tunnelling and Underground Space Technology, 2017, 66: 134-146

173. Zhu H, Shen Y, Yan Z, Guo Q, Guo Q. A numerical study on the feasibility and efficiency of point smoke extraction strategies in large cross-section shield tunnel fires using CFD modeling. Journal of Loss Prevention in the Process Industries, 2016, 44: 158-170

174. Guo Q, Zhu H, Yan Z, Zhang Y, Zhang Y, Huang T. Experimental studies on the gas temperature and smoke back-layering length of fires in a shallow urban road tunnel with large cross-sectional vertical shafts. Tunnelling and Underground Space Technology, 2019, 83: 565-576

175. Zhang T, Zhang Y, Xiao Z, Yang Z, Zhu H, Ju J W, Yan Z. Development of a novel bio-inspired cement-based composite material to improve the fire resistance of engineering structures. Construction \& Building Materials, 2019, 225: 99-111

176. Yan Z G, Shen Y, Zhu H H, Li X, Lu Y. Experimental investigation of reinforced concrete and hybrid fibre reinforced concrete shield tunnel segments subjected to elevated temperature. Fire Safety Journal, 2015, 71: 86-99

177. Zhang Y, Yan Z, Zhu H, Shen Y, Guo Q, Guo Q. Experimental investigation of pedestrian evacuation using an extra-long steepslope evacuation path in a high altitude tunnel fire. Sustainable Cities and Society, 2019, 46: 101423

178. Guo Q, Zhu H, Zhang Y, Yan Z. Theoretical and experimental studies on the fire-induced smoke flow in naturally ventilated tunnels with large cross-sectional vertical shafts. Tunnelling and Underground Space Technology, 2020, 99: 103359

179. Kallianiotis A, Papakonstantinou D, Arvelaki V, Benardos A. Evaluation of evacuation methods in underground metro stations. International Journal of Disaster Risk Reduction, 2018, 31: 526534

180. Bettelini M. Systems approach to underground safety. Underground Space, 2020, 5(3): 258-266

181. Yan Z, Zhang Y, Guo Q, Zhu H, Shen Y, Guo Q. Numerical study on the smoke control using point extraction strategy in a large cross-section tunnel in fire. Tunnelling and Underground Space Technology, 2018, 82: 455-467

182. Lyu H M, Shen S L, Zhou A N, Yang J. Perspectives for flood risk assessment and management for mega-city metro system. Tunnelling and Underground Space Technology, 2019, 84: 31-44

183. Yang Z S, Peng F L, Qiao Y K, Hu Y Y. A new cryogenic sealing process for the launch and reception of a tunnel shield. Tunnelling and Underground Space Technology, 2019, 85: 406-417

184. Peng F L, Dong Y H, Wang H L, Jia J W, Li Y L. Remote-control technology performance for excavation with pneumatic caisson in soft ground. Automation in Construction, 2019, 105: 102834

185. Zhu H, Ding W, Qiao Y, Xie D. Micro-disturbed construction control technology system for shield driven tunnels and its application. Chinese Journal of Geotechnical Engineering, 2014, 36(11): 1983-1993 (in Chinese)

186. Nakai M. Preservation and restoration of Tokyo Station Marunouchi Building. Japan Railway Transport Review, 2013, 61: 615

187. Namikawa K, Terashima Y, Inoue T, Koseki J, Miyashita Y, Matsumoto M. Construction of Expressway Branch Junction Structure Using Non-Cut-and-Cover Enlargement Method to Combine Two Shield Tunnels in Sedimentary Soft Rock. 2016

188. Zhu H, Yan J, Liang W. Challenges and development prospects of ultra-long and ultra-deep mountain tunnels. Engineering (Beijing), 2019, 5(3): 384-392

189. von der Tann L, Metje N, Admiraal H, Collins B. The hidden role of the subsurface for cities. Proceedings of the Institution of Civil Engineers. Civil Engineering, 2018, 171(6): 31-37

190. Rajabifard A. Sustainable Development Goals Connectivity Dilemma: Land and Geospatial Information for Urban and Rural Resilience. Boca Raton: CRC Press, 2020

191. Rajabifard A, Sabri S, Chen Y, Agunbiade M, Kalantari M. Urban analytics data infrastructure: Critical SDI for measuring and monitoring the national and local process of SDGs. Sustainable Development Goals Connectivity Dilemma (Open Access): Land and Geospatial Information for Urban and Rural Resilience. Boca Raton: CRC Press, 2020,243-256

192. Maring L, Blauw M. Asset management to support urban land and subsurface management. Science of the Total Environment, 2018, 615: 390-397

193. Kalantari M, Rajabifard A, Olfat H, Pettit C, Keshtiarast A. Automatic spatial metadata systems - The case of Australian urban research infrastructure network. Cartography and Geographic Information Science, 2017, 44(4): 327-337

194. CSDILA. Fishermans bend digital twin project. Coordinates, 2019, 15(10): $37-38$ 